\title{
Gulf Cooperation Council (GCC) and Regional Integration in Asia
}

http://doi.org/10.21272/fmir.5(1).61-79.2021

Dr. Debesh Bhowmik, ORCID: https://orcid.org/0000-0002-0293-1066

Retired Principal and Honorary Research Professor, Lincoln University College, Malaysia

\begin{abstract}
In Asia, SAARC (South Asian Association of Regional Cooperation), ASEAN (Association of South East Asian Nations) and GCC (Gulf Cooperation Council) are being considered as an active regional trading blocs although East Asian integration is on primary cooperation stage and BIMSTEC is treated as organised sub-regional trading bloc. The GCC has completed all criterion of economic integration except introduction of a single currency and ASEAN is advancing its optimum stage of monetary integration but the advancement of SAARC is halted by the shock of non-cooperation from Pakistan. Therefore, contribution of GCC in integrating Asian bloc is to scrutinise in a new outlook. In this paper, the author endeavours to show the impact of economic integration of Gulf Cooperation Council (GCC) on the Asian economic integration in the sense that the process of integration of GCC with SAARC and ASEAN can accelerate the criterion of Asian integration process. Therefore, the author used cointegration and vector error correction model among the indicators of trade integration of exports such as Asian export share, intra export share of GCC, export concentration index of GCC, ASEAN's export with GCC and SAARC's export with GCC during 1995-2019. Similarly, the author applied same methodology among the trade indicator of imports such as Asian import share, intra import share of GCC, import concentration index of GCC, ASEAN's import with GCC and SAARC's import with GCC during the specified period. The findings revealed that Asian export share has long run significant causalities with SAARC and ASEAN export shares to GCC. Intra export share of GCC has long run causalities with SAARC and ASEAN export shares to GCC. The export concentration index of GCC has significant long run causalities with SAARC and ASEAN export shares to GCC respectively. Even, the short run causalities from export concentration index of GCC to intra export share of GCC, export share of ASEAN and SAARC with GCC and the short run causality from ASEAN export share with GCC to export share of Asia and from intra export share of GCC to export share of ASEAN with GCC were strictly observed. Again, the import share of Asia has long run causalities with the import shares of ASEAN and SAARC with GCC. The intra import share of GCC has long run causalities with the import shares of ASEAN and SAARC with GCC and the import concentration index of GCC has long run causalities with the import shares of ASEAN and SAARC with GCC respectively. The intra import share of GCC has short run causalities with import share of Asia, import concentration index of GCC and import share of ASEAN with GCC respectively. The import concentration index has short run causality with the import share of Asia. The import share of SAARC with GCC has short run causality with import share of ASEAN with GCC. The cointegration and vector error correction among Asian GDP, sum of intra export and import shares of GCC, sum of export and import shares of ASEAN with GCC, and sum of export and import shares of SAARC with GCC during 1995-2019 indicated that the GDP of Asia has long run causalities with the sum of intra export and import shares of GCC, the sum of export and import shares of ASEAN with GCC and the sum of export and import shares of SAARC with GCC and even they have short run causalities also. All these observations can justify that GCC has great impact on Asian economic integration process associated with SAARC and ASEAN.
\end{abstract}

JEL Classification: B22, C01, C22, C33, F15, F53, F55, N25

Keywords: Gulf Cooperation Council, Asian integration, SAARC, ASEAN, Growth, intra export share, intra import share, Asian share, export concentration index, import concentration index.

Cite as: Bhowmik, D. (2021). Gulf Cooperation Council (GCC) and Regional Integration in Asia. Financial Markets, Institutions and Risks, 5(1), 61-79. http://doi.org/10.21272/fmir.5(1).61-79.2021

Received: 18 January 2021

Accepted: 25 February 2021

Published: 30 March 2021

Copyright: (C) 2021 by the author. Licensee Sumy State University, Ukraine. This article is an open access article distributed under the terms and conditions of the Creative Commons Attribution (CC BY) license (https://creativecommons.org/licenses/by/4.0/)

\section{Introduction}

The Gulf Cooperation Council (GCC) is consisting of six countries namely, United Arab Emirates, Saudi Arabia, Qatar, Oman, Kuwait and Bahrain respectively and was set up on $11^{\text {th }}$ November, 1981.The bloc has 
created custom union in January 2003, established common market in 2007 and planned to issue common currency in 2010 although it had not introduced till today. Its GDP is 1.638 trillion US\$ which is $11^{\text {th }}$ in the world and its GDP per capita is estimated as 71205 US\$ whose rank is $7^{\text {th }}$ in the world. The human development index of GCC is quite high of 0.840 with a low Gini of 28.7 which implies that inequality of income is low. The world export and import shares of GCC are now $4.088 \%$ and $2.693 \%$ and its' Asian export and import shares are $40.875 \%$ and $37.747 \%$ respectively in 2019 . The intra export and import shares of GCC are $10.66 \%$ and $2.693 \%$ respectively in 2019.The bloc GCC has been growing unprecedently since its intra export and import shares have been catapulting at the rates of $1.76 \%$ and $2.26 \%$ per year during 1995-2019 and its export share and import share with ASEAN have been rising at the rates of $9.32 \%$ and $8.08 \%$ per year and moreover its export and import shares with SAARC have been increasing at the rates of $8.76 \%$ and $7.93 \%$ respectively during the same period.

The role of GCC in Asian economic integration cannot be denied at all. Its economic and political relation with SAARC and ASEAN in speeding up integration process showed a new light in regional and sub-regional growth of trade and development specially in Asia and in the Indian Ocean region.

The several ASEAN-GCC ministerial meetings since 2009 June, followed by 2010June \& November,2011May \& 2011June and in 2013November revealed the fruitful cooperation in the areas of education, tourism, food security and agricultural investment, economic cooperation and development and free trade areas and so on. The Ministers between GCC and ASEAN also committed to further strengthen and promote cooperation in the areas of energy, climate change, food security, people-to-people contacts, tourism and education, and further expressed support for enhancing the prospects of future cooperation in the fields of labour, improving preparedness for future global economic crisis, enhanced consular cooperation, electricity, water, transport, communications, planning, development, communications and information technology respectively.

The SAARC-GCC trade cooperation is rather complex since UNESCAP (2017) argued that the intergovernmental institutions (among 11 regional institutions, only 6 have trade agreements in force) formulated GCC's custom union which removed all internal tariff barriers and imposed a common external tariff to SAFTA between SAARC members.

GCC is a net importer of food from SAARC and SAARC is a net importer of oil and gas from GCC. But GCC faced huge trade barriers from SAARC and other Asian countries while GCC's tariff rate ranges from 1.5\%$2 \%$ to South Asia.

India-GCC economic relationship is quite bold and historic since India imports $42 \%$ of oil from GCC and it is the largest regional trading bloc but India-GCC free trade agreement is not yet finalised although agreement in economic cooperation was signed in August 2004. India-Gulf region's sea lines of communication remains open and flowing. Moreover, India-Gulf naval security through Indian ocean was established in 2008.

China-GCC negotiations opened in June 22-24,2009. China- GCC trade and economic joint committee discussed on 31 July,2011 for boosting bilateral trade, investment and technological co-operation. China imported oil from GCC states and exported machinery, electronic products, garments and luggage etc. Chinese FDI to GCC has been catapulting gradually. China-GCC FTA which was introduced in 2009 can promote bilateral trade and East Asian trade integration (Chen,2011).

GCC-Japan economic relation depends on trade cooperation with diplomatic strategy since 1955 in association with USA on the issue of security and development assistances. GCC-Japan FTA negotiations since 2006 were on dynamic process in the areas of trade and investment, rules of origin, custom procedures and disputes settlements etc to achieve liberalisation consistent with WTO. Japan imports oil from GCC and exports motor vehicles, machinery, iron/steel, electronic machines, rubber, textiles and foodstuffs etc (Calder,2015).

Thus, the central aims of the paper are to find out the factors of GCC's trade with SAARC and ASEAN by which can influence trade of Asia where the paper selected the determinants such as GCC's export and import share with SAARC, export and import concentration index of GCC in one hand and GCC's export and import shares with ASEAN on the other hand. Even, the paper tried to check the impact of intra export and intra import of GCC on Asia's trade (Asia's export and import share) so that the results can infer the progress of trade integration in Asia. How much the impact on Asia's growth and development due to GCC's trade with 
Financial Markets, Institutions and Risks, Volume 5, Issue 1, 2021 ISSN (online) - 2521-1242 ISSN (print) - 2521-1250

SAARC and ASEAN was done through the indicators of sum of exports and import of GCC with SAARC and ASEAN and sum of intra export and import share of GCC and the aggregate GDP of Asia.

On the basis of the aims, the author endeavours to examine the impact of trade integration of GCC with SAARC and ASEAN on the trade integration of Asia subject to the said determinants and secondly, it examines the impact of aggregate trade indicators of GCC with SAARC and ASEAN on the aggregate GDP of Asian region by applying the methodology of Johansen cointegration and vector error correction models during 1995-2019 taking data from UNCTAD.

\section{Some important studies}

The author has incorporated a few relevant econometric and analytical research papers in the section of review of economic literature.

Wilson (2004) studied the economic cooperation among GCC, South Asia and ASEAN on financial assistance, development assistance, interbank transactions, citizen's portfolios and capital flows during 1970-1990.

Song (2010) cited many ministerial negotiations between GCC and ASEAN in the field of economic integration process since 1990 especially in common market, trade cooperation in "food for oil", social and economic security. The author showed the prospects and problems of ASEAN-GCC free trade area, promotion of trade and financial cooperation and infrastructure development, migration and tourism.

Pradhan (2010) studied the GCC-SAARC economic relations in the new strategic geo-economic interactions involving energy and Petro-dollar investment, cheap consumer goods, knowledge-driven technologies and migrant labour etc. During 2004 - 2008, their trade increased more than six-fold including tourism. Now both GCC and SAARC become interested in spread to investment, labour migration, remittances, food security, etc.

Al-Tamimi (2013) explained the trade relationship between GCC and Asia which rose substantially over the past few years and Asia accounts for nearly $60 \%$ of GCC's total foreign trade. Asia's demand for energy is largely supplied by GCC and expected $90 \%$ of oil exports from the Middle East in the future where India and China are the dominant countries in Asia and this trade relationship might enhance GCC-Asia integration process.

The study of Koerner (2014) stated that the GCC's export to Non-Japan Asia are dominated by oil and gas as well as petroleum and plastic which account more than $80 \%$ of total export. Non-Japan Asia absorbs almost $60 \%$ of the GCC's energy export. China's oil import from GCC accounts $30 \%$ and Japan's import is found as $60 \%$. The increased mutual investment interest between GCC and developing Asia has been intensified recently. From 2005- to 2012 Chinese FDI was $8 \%$ of all FDI but Chinese FDI into GCC is very small. GCC has close relation for FDI inflows and outflows from India, Pakistan, UK and USA etc. The relation of GCC with growing Asian market is linked with tele-communication and Islamic finance, research and development in high technology with transfer of technology and nuclear energy.

Janardhan (2014) analysed the prospects on ASEAN-China and GCC-Iran Ties which emphasised on Look East Policy. The paper studied the GCC-Asia Strategic Co-operation on security around Indian Ocean Rim Association especially on peace and stability with the influence of USA. Other than SAARC and ASEAN, GCC maintained economic cooperation with India, South Korea, Japan and USA.

Bhowmik (2014) cited the existence of GCC in Asian economic and trade cooperation excluding the performance in details but intended to focus on the role of SAARC+ ASEAN+EA which is politically and geographically compact, feasible and sustainable towards the process of Asian Economic Integration.

Cinar et al. (2016) applied gravity model with counter factual methods to explain the trade between GCC and China citing the uses of former silk road during 1990-2013 and found that trade of GCC with China needs to recognise the possible interests of growth in China.

The gravity model of Kodithuwakku et al. (2016) between SAARC and GCC on food and agricultural export found that dependence of GCC on SAARC increased gradually where it rose from 13\% to $15 \%$ from 2007 to 2012 where India was the leading country with higher trade intensity.

Zhen and Xinyi (2017) studied the dynamism of the Indian Ocean Regional integration analysis historically through the activities and establishment of SAARC, ASEAN, GCC, SADC, COMESA and IORA respectively. Their roles in trade integration in Asia, trade controls and regulations in custom union, regional convergence and coherence were also analysed. 
In an essay in UKEssays (2018), it was found that GCC and ASEAN trade agreement and the economic integration were emphasised by Trade and Investment Framework Agreement, Free Trade Area, trade and investment opportunities, trade agreements with Singapore, ASEAN-GCC Action Plan and foreign direct investment respectively.

Pangestu and Armstrong (2018) explained that the plan of Asian Economic Community as well as framework of RCEP have potential effects for balancing China and Japan led Asian integration process and boosting for regional integration in Asia where the reform of RTA should be the prior agenda. Although, US led plurilateral agreement TPP and US-EU led TTIP in Asian integration process have been presented a balancing effect in $21^{\text {st }}$ century in ASEAN+1 FTA program towards trade liberalisation in APEC. In this context, Nayyar (2018) wrote that a non-starter SAFTA, China minus East Asian Strategy, India-ASEAN FTA and non-introduction of ASEAN single currency are the major stumbling blocks in the progress of Asian Integration.

Adhikari et al. (2019) studied migration problem of South Asia with GCC analytically and stated that GCC and South Asian Region is the lowest cost corridor for remittance transfers as a result of migration of labour which vitalises the integration process. Both regular and irregular migrants from SAARC nations to GCC needs the affirmation of laws of migration and their social safety nets. It requires ministerial conference between GCC and SAARC and ASEAN with the initiative of ILO to implement policies of migration management relating to employment that may revitalise the Asian growth and integration.

Burton (2020) showed relation between GCC, India, China, Japan and Korea focussing energy dimension, exchanges, co-operation, partnership, foreign direct investment, link in roads and transport, investment in real estate, health care and financial services, security in Asian states etc. The paper also discussed on trade cooperation and strategy in future and concrete future plan on uncertainty.

Asian Development Bank (2021) assessed in its Asian Economic Integration Report 2021 that the integration process succeeded a lot yet to proceed a long way although the report is silent about the GCC. The assessments are as follows:[i]Asia has relatively strong regional value chain linkages as measured by regional value chain of global value chain integrity ratio although it emphasised new free trade agreement and subregional cooperation in CAREC, BIMSTEC,GMS and SASEC etc.[ii] Cross border investment is rising,[iii] Regional integration measured by integration index has been moving ahead,[iv] Regional co-operation must be strengthened although financial integration process is halted by covid-19 pandemic , [v] Digital technology improvement is essential.

\section{Methodology and Source of Data}

The paper assumed:

$\mathrm{IX}=$ Intra export share of GCC (\% of bloc),IM=Intra import share of $\mathrm{GCC}(\%$ of bloc $)$, XCI =export concentration index of GCC,ICI=Import concentration index of GCC, GAM=Import of GCC from ASEAN(in million US\$), GAX=export of GCC from ASEAN(in million US\$), GSM=import of GCC from SAARC(in million US\$),GSX=export of GCC from SAARC(in million US\$),GDPA=GDP of Asia in billion US\$.,XA=export share of Asia (\% of world), IA=Import share of Asia(\% of the world). The data of these variables have been collected from UNCTAD (https://unctadstat.unctad.org/wds/TableViewer/ tableView.aspx?ReportId=24397 Report Id=24397).

The semi-log linear regression model is used to clarify the growth rates. The estimated equation can be written as: $\log \left(\mathrm{x}_{\mathrm{i}}\right)=\mathrm{a}+\mathrm{bt}+\mathrm{u}_{\mathrm{i}}$ where $\mathrm{x}_{\mathrm{i}}=$ variable to be estimated, $\mathrm{a}$ and $\mathrm{b}$ are constants, $\mathrm{t}=\mathrm{time}(\mathrm{year})$, $\mathrm{u}_{\mathrm{i}}=$ random error, for all values of $i=1,2,3, \ldots \ldots \ldots . n$.

Cointegration and Vector Error Correction models of Johansen $(1988,1991)$ have been applied for long run association and causalities among the variables.

The approach of Johansen models $(1988,1991)$ has been elaborated below in brief.

If the $\mathrm{mx} 1$ vector time series $\mathrm{Y}_{\mathrm{t}}$ contains more than 2 components, each being $\mathrm{I}(1)$, then there may exist $\mathrm{k}(<\mathrm{m})$ linearly independent $1 \mathrm{xm}$ vectors $\alpha_{1}, \alpha_{2} \ldots \ldots \alpha_{\mathrm{k}}$ such that $\alpha^{\prime} \mathrm{y}_{\mathrm{t}} \sim \mathrm{I}(0) \mathrm{kx} 1$ vector process where $\alpha=\left(\alpha_{1}, \alpha_{2} \ldots \ldots \alpha_{\mathrm{k}}\right)$ is a $\mathrm{kx}$ m cointegrating matrix.

Let VAR(p) [Vector Auto Regressive] model is given below,

$\mathrm{Y}_{\mathrm{t}}=\delta \mathrm{D}_{\mathrm{t}}+\phi_{1} \mathrm{Y}_{\mathrm{t}-1}+\ldots \ldots \ldots \ldots+\phi_{\mathrm{p}} \mathrm{Y}_{\mathrm{t}-\mathrm{p}}+\varepsilon_{\mathrm{t}}$ 
Where $Y_{t}$ is a time series mx 1 vector of $I(1)$ variables. The VAR(p) model is stable if

Determinant (In- $\phi_{1} \mathrm{z}$ $\left.-\phi_{\mathrm{p}} z^{\mathrm{p}}\right)=0$

If there are roots on the unit circle then some or all the variables in $\mathrm{Y}_{\mathrm{t}}$ are $\mathrm{I}(1)$ and they may be cointegrated. If cointegration exists the VAR model is transferred to VECM (Vector Error Correction Model) which is given below.

$\Delta \mathrm{Y}_{\mathrm{t}}=\Gamma_{0} \mathrm{D}_{\mathrm{t}}+\Pi \mathrm{Y}_{\mathrm{t}-1}+\sum_{j=1}^{p-1} \Gamma j \Delta \mathrm{Y}_{t-j}+\varepsilon_{\mathrm{t}}$

Where $\mathrm{D}_{\mathrm{t}}=$ vector deterministic variables (constants, trends, and/or seasonal dummy variables)

$\Gamma \mathrm{j}=-\mathrm{I}+\phi_{1}+\ldots \ldots \ldots . \phi_{\mathrm{j}}$, for all values $\mathrm{j}=1,2, \ldots \ldots \ldots . \mathrm{p}-1$ are mxm matrix.

$\Pi=\gamma \mathrm{A}$ is the long run impact matrix, $\mathrm{A}$ and $\gamma$ are mxk matrices,

$\varepsilon_{\mathrm{t}}$ are $\mathrm{Nm}(0, \Sigma)$ errors.

Determinant $\left(1-\sum_{j=1}^{p-1} \Gamma \mathrm{j} B^{j}\right)$ has all its roots outside the unit circle.

Assume VECM errors are independent $\mathrm{Nm}(0, \Sigma)$ distribution, then given CI restrictions on the trends/drift/no drift parameters, the likelihood $\mathrm{L}_{\max }(\mathrm{k})$ is a function of the $\mathrm{CI}$ rank $\mathrm{k}$.

The Trace test is based on log-likelihood ratio (LR),

$\mathrm{LR}=2 \ln \left[\mathrm{L}_{\max }(\right.$ unrestricted $) / \mathrm{L}_{\max }($ restricted $\left.)\right]$ for $\mathrm{k}=\mathrm{m}-1, \ldots \ldots \ldots 1,0$.

The Test $\mathrm{H}_{0}: \mathrm{CI}$ rank $\leq \mathrm{k}$ Vs $\mathrm{H}_{1}: \mathrm{CI}$ rank $>\mathrm{k}$. If the $\mathrm{LR}$ is greater than the critical value for a certain rank, then $\mathrm{H}_{0}$ is rejected.

The Trace Test: $\mathrm{LR}_{\text {trace }}(\mathrm{k})=-2 \ln \Lambda=-\mathrm{T} \sum_{i=k+1}^{m} \ln (1-\lambda i)$ where $\lambda_{\mathrm{i}}$ denotes the descending ordered Eigen values $\lambda_{1}>\lambda_{2}>\ldots \ldots .>\lambda_{m}>0$ of the determinant $\left(\lambda \mathrm{S}_{11}-\mathrm{S}_{10} \mathrm{~S}_{00} 0^{-1} \mathrm{~S}_{01}\right)=0$

If $\mathrm{LR}_{\text {trace }}(\mathrm{k})>\mathrm{CV}$ (for rank $\mathrm{k}$ ), then $\mathrm{H}_{0}(\mathrm{CI}$ rank $\mathrm{k}$ ) is rejected.

Alternatively,

$\mathrm{LR}_{\max }(\mathrm{k})=-2 \ln \Lambda=-\ln \left(1-\lambda_{\mathrm{k}+1}\right)$ is called the maximal Eigen value statistic. Test $\mathrm{H}_{0}: \mathrm{CI}$ rank $=\mathrm{k} \mathrm{Vs} \mathrm{H}_{1}: \mathrm{CI}$ rank $=\mathrm{k}+1$.

The unit circle and impulse response functions analysis were applied in the residual test to verify the stability and stationarity of VECM. The cointegrating equation usually expressed the long run causality of the variables.

The impulse response function can be expressed as MA (Moving Average) process which is derived from VAR(p) model as,

$\mathrm{Y}_{\mathrm{t}}=\mathrm{c}+\varepsilon_{\mathrm{t}}+\psi_{1} \varepsilon_{\mathrm{t}-1}+\psi_{2} \varepsilon_{\mathrm{t}-2}+\ldots \ldots \psi(\mathrm{B}) \varepsilon_{\mathrm{t}}$

$\Delta \mathrm{y}_{\mathrm{t}+1} / \delta \varepsilon_{\mathrm{t}}=\psi_{1}$

The row $i$, column $j$ element of $\psi_{1}$ identifies the consequences of one unit increase in the jth variable's innovation at date $t\left(\varepsilon_{\mathrm{t}}\right)$ for the value of the ith variable at time $\mathrm{t}+1$, holding all other innovations at all dates constant. A plot of the row i,column $\mathrm{j}$ element of as a function of lag 1 is called the non-orthogonalized impulse response function.

To justify the short run causality the Wald Test (1943) has been applied for analysis.

The Wald test (1943) has been explained in brief which is relevant in this analysis.

$\mathrm{Y}_{\mathrm{t}}$ in a VAR(p) process if divided into sub-processes $\mathrm{Z}_{\mathrm{t}}$ and $\mathrm{x}_{\mathrm{t}}$ i.e., $\ddot{\mathrm{Y}}_{\mathrm{t}}=\left(\dot{\mathrm{x}}_{\mathrm{t}}, \dot{\mathrm{Z}}_{\mathrm{t}}\right)$.Causality is defined by zero constraints on VAR coefficients and when in $\operatorname{VAR}(p)$ system, it is tested zero constraints for the coefficients to derive asymptotic test considering $\mathrm{ca}=\mathrm{c}<=>\mathrm{A}_{\mathrm{jki}}=0$ in a manner of :

$\mathrm{H}_{0}: \mathrm{ca}=\mathrm{c}$ against $\mathrm{H}_{1}: \mathrm{ca} \neq \mathrm{c}$ where $\mathrm{c}$ is an $\mathrm{Nx}\left(\mathrm{k}^{2} \mathrm{p}+\mathrm{k}\right)$ matrix of rank $\mathrm{N}$ and $\mathrm{c}$ is an $(\mathrm{Nx} 1)$ vector. Assuming that $\sqrt{T}(\mathrm{cä}$ -a) $\cap \mathrm{N}\left[\left(0, \Gamma^{-1} \Sigma_{\mathrm{u}}\right)\right]$ is an least square/maximum likelihood estimation and then we get $\sqrt{ } \mathrm{T}(\mathrm{cä}-\mathrm{ca}) \cap \mathrm{N}\left[0, \mathrm{c}\left(\Gamma^{-1} \Sigma_{\mathrm{u}}\right) \mathrm{c}^{\prime}\right]$ . Hence the Wald statistic is given by

$\mathrm{T}(\mathrm{cä}-\mathrm{c})^{\prime}\left[\mathrm{c}\left(\Gamma^{-1} \Sigma_{\mathrm{u}}\right) \mathrm{c}^{\prime}\right]^{-1}(\mathrm{cä}-\mathrm{c}) \cap \chi 2(\mathrm{~N})$

Then we replace $\Gamma$ and $I_{u}$ by their unusual estimator 
$\Gamma^{\prime}=\mathrm{zz} / \mathrm{T}$ and $\Sigma_{\mathrm{u}}^{\prime}=\mathrm{T} /\left(\mathrm{T}-\mathrm{k}_{\mathrm{p}}-1\right) \mathrm{x} \Sigma_{\mathrm{u}}^{\prime}$, then the resulting statistic becomes

$\lambda_{\mathrm{w}}=(\mathrm{cä}-\mathrm{a})^{\prime}\left[\mathrm{c}\left((\mathrm{zz})^{-1} \Sigma_{\mathrm{u}}^{\prime}\right) \mathrm{c}^{\prime}\right]^{-1}(\mathrm{cä}-\mathrm{c})$

It is still asymptotic $\chi^{2}$ distribution with $\mathrm{N}$ degree of freedom and it has the condition of $\left[\mathrm{c}\left((\mathrm{zz})^{-1} \Sigma_{\mathrm{u}}^{\prime}\right)^{\prime}\right]^{-1 / T}$ which is a consistent estimator of $\left[\mathrm{c}\left(\Gamma^{-1} \Sigma_{\mathrm{u}}\right) \mathrm{c}^{-1}\right]^{-1}$

Hence, we have the following result: The asymptotic distribution of the Wald statistic supposed:

$\sqrt{T}$ (cä $-\mathrm{a}) \cap \mathrm{N}\left[\left(0, \Gamma^{-1} \Sigma_{\mathrm{u}}\right)\right]$ holds and in practice, $\mathrm{NF}(\mathrm{N}, \mathrm{T}) \cap \chi 2(\mathrm{~N})$ as $\mathrm{t}$ tends to infinity where $\mathrm{F}(\mathrm{N}, \mathrm{T})$ indicates as $\mathrm{F}$ random variable with $\mathrm{N}$ and $\mathrm{T}$ degrees of freedom because $\mathrm{F}(\mathrm{N}, \mathrm{T})$ distribution has flatter tail than the $\chi 2(\mathrm{~N}) / \mathrm{N}$ distribution and it is reasonable to consider the test statistic $\lambda_{\mathrm{F}}=\lambda_{\mathrm{w}} / \mathrm{N}$ in conjunction with critical values from the $\mathrm{F}$ distribution.

\section{Results and Observations of Econometric models}

1. Impact of GCC on Asian integration. Asian export share, intra export share of GCC, export concentration index of GCC, ASEAN's export with GCC and SAARC's export with GCC during 1995-2019 have long run association as evident from Johansen unrestricted cointegration test among the first difference series of those variables with linear deterministic trend in which Trace statistic and Max Eigen statistic produced three cointegrating equations each. The values of statistic with probabilities of critical values of $5 \%$ significant level are shown below in Table 1. It implies that SAARC and ASEAN exports with GCC and intra export of GCC have greatly influenced the Asian export share in the long run which developed the economic integration in Asia.

Table 1. Johansen cointegration

\begin{tabular}{|c|c|c|c|c|}
\hline $\begin{array}{l}\text { Hypothesized } \\
\text { No. of CE(s) }\end{array}$ & Eigenvalue & $\begin{array}{c}\text { Trace } \\
\text { Statistic }\end{array}$ & $\begin{array}{c}0.05 \\
\text { Critical Value }\end{array}$ & Probability** \\
\hline None $*$ & 0.898114 & 122.8232 & 69.81889 & 0.0000 \\
\hline At most $1 *$ & 0.785900 & 70.29349 & 47.85613 & 0.0001 \\
\hline At most $2 *$ & 0.612173 & 34.84329 & 29.79707 & 0.0120 \\
\hline At most 3 & 0.413674 & 13.05780 & 15.49471 & 0.1127 \\
\hline At most 4 & 0.033284 & 0.778561 & 3.841466 & 0.3776 \\
\hline & & Max-Eigen Statistic & & \\
\hline None * & 0.898114 & 52.52966 & 33.87687 & 0.0001 \\
\hline At most $1 *$ & 0.785900 & 35.45021 & 27.58434 & 0.0040 \\
\hline At most $2 *$ & 0.612173 & 21.78549 & 21.13162 & 0.0404 \\
\hline At most 3 & 0.413674 & 12.27923 & 14.26460 & 0.1006 \\
\hline At most 4 & 0.033284 & 0.778561 & 3.841466 & 0.3776 \\
\hline
\end{tabular}

* denotes rejection of the hypothesis at the 0.05 level, **MacKinnon-Haug-Michelis (1999) p-values, Total observations after adjustment=23.

Source-Calculated by author.

The estimated first equation of VECM revealed that the incremental Asian export share is insignificantly positively related with previous period's incremental intra export share of GCC, export concentration index of GCC, SAARC export to GCC respectively but is significantly negatively related with the incremental ASEAN's export to GCC of the earlier period. Here, three error correction terms are insignificant but they are moving towards equilibrium. The values of $\mathrm{F}$ and $\mathrm{R}^{2}$ are low. In the second equation, it was found that the incremental intra export share of GCC is insignificantly negatively related with incremental export share of Asia and SAARC export to GCC of the previous period but significantly negatively related with incremental export concentration index of GCC of earlier period and even insignificantly positively related with ASEAN export of GCC of the previous period. The values of $\mathrm{R}^{2}$ and $\mathrm{F}$ are high.EC1 is convergent but EC2 and EC3 are divergent where all of the three are insignificant. The estimated third equation states that the incremental export concentration index of GCC is insignificantly positively related with previous period of incremental export share of Asia, intra export share of GCC and export of SAARC to GCC but insignificantly negatively related with export share of ASEAN to GCC of the previous period. Here, $\mathrm{R}^{2}$ is medium and $\mathrm{F}$ is insignificant. The three error correction terms are insignificant but convergent. The estimated fourth equation implies that the change of ASEAN's export share to GCC is significantly positively influenced by incremental export concentration index of GCC and intra export share of GCC of the previous period and insignificantly positively related with incremental export share of SAARC to GCC of earlier period. Here, $\mathrm{R}^{2}$ is high and $\mathrm{F}$ is significant.EC1 is divergent but EC2 and EC3 are convergent and EC2 is significant. The estimated fifth equation states that the change of export share of SAARC to GCC is insignificantly positively related with incremental intra export share and export concentration index of GCC of previous period and insignificantly 
negatively related with previous period's incremental export share of Asia and export share of ASEAN to GCC respectively. The $\mathrm{R}^{2}$ is high with significant $\mathrm{F}$. The EC1 is divergent and significant, EC2 is convergent and significant and EC3 is convergent and insignificant.

Table 2. Vector Error Correction Model

\begin{tabular}{|c|c|c|c|c|c|}
\hline & $\mathrm{dXA}_{\mathrm{t}}$ & $\mathrm{dIX}_{\mathrm{t}}$ & $\mathrm{dXCI} \mathrm{X}_{\mathrm{t}}$ & $\mathrm{dGAX}_{\mathrm{t}}$ & $\mathrm{dGSX}_{\mathrm{t}}$ \\
\hline EC1 & -0.427357 & -0.183830 & -0.004730 & 5216.104 & 7976.464 \\
\hline $\mathrm{t}$ values & {$[-1.32225]$} & {$[-0.89582]$} & {$[-0.42672]$} & {$[1.63124]$} & {$[2.01414]^{*}$} \\
\hline EC2 & -0.637881 & 0.421483 & -0.024038 & -18392.90 & -14836.30 \\
\hline t values & {$[-1.18619]$} & [ 1.23446$]$ & {$[-1.30344]$} & {$[-3.45711]^{*}$} & {$[-2.25162]^{*}$} \\
\hline EC3 & -21.58151 & 8.474395 & -0.720506 & -213798.1 & -71806.69 \\
\hline t values & {$[-1.83544]$} & [1.13514] & {$[-1.78681]$} & {$[-1.83785]$} & {$[-0.49840]$} \\
\hline $\mathrm{dXA}_{\mathrm{t}-1}$ & 0.031957 & -0.246469 & 0.007779 & -518.8528 & -1860.185 \\
\hline $\mathrm{t}$ values & {$[0.10025]$} & {$[-1.21783]$} & {$[0.71161]$} & {$[-0.16453]$} & {$[-0.47627]$} \\
\hline $\mathrm{dIX}_{\mathrm{t}-1}$ & 0.426761 & -1.274874 & 0.028037 & 12907.14 & 10787.12 \\
\hline $\mathrm{t}$ values & [0.90932] & {$[-4.27842]^{*}$} & [1.74202] & {$[2.77979]^{*}$} & [ 1.87583$]$ \\
\hline $\mathrm{dXCI} \mathrm{X}_{-1}$ & 36.04580 & -33.21719 & 0.975219 & 507157.8 & 443710.8 \\
\hline $\mathrm{t}$ values & [1.94068] & {$[-2.81673]^{*}$} & [1.53103] & {$[2.75989]^{*}$} & [ 1.94964$]$ \\
\hline $\mathrm{dGAX}_{\mathrm{t}-1}$ & -0.000186 & $3.86 \mathrm{E}-05$ & $-2.60 \mathrm{E}-06$ & -0.991979 & -1.286571 \\
\hline $\mathrm{t}$ values & {$[-2.35149]^{*}$} & {$[0.76715]$} & {$[-0.95578]$} & {$[-1.26478]$} & {$[-1.32451]$} \\
\hline $\mathrm{dGSX}_{\mathrm{t}-1}$ & 0.000106 & $-3.66 \mathrm{E}-05$ & $2.17 \mathrm{E}-06$ & 0.661380 & 1.006094 \\
\hline $\mathrm{t}$ values & [ 1.77665$]$ & {$[-0.96821]$} & [ 1.06351$]$ & [ 1.12250$]$ & [ 1.37874$]$ \\
\hline $\mathrm{C}$ & 0.908849 & 0.210557 & -0.009715 & 6164.525 & 7547.461 \\
\hline t values & {$[2.42668]^{*}$} & [ 0.88547$]$ & {$[-0.75637]$} & [ 1.66368$]$ & [ 1.64467$]$ \\
\hline R-squared & 0.363794 & 0.752163 & 0.490428 & 0.763146 & 0.705587 \\
\hline F-statistic & 1.000683 & 5.311106 & 1.684256 & 5.638531 & 4.194030 \\
\hline Akaike AIC & 3.091830 & 2.183306 & -3.653747 & 21.49110 & 21.91889 \\
\hline Schwarz SC & 3.536154 & 2.627629 & -3.209423 & 21.93542 & 22.36321 \\
\hline
\end{tabular}

$\mathrm{n}=23$ (after adjustment), ${ }^{*}=$ significant at $5 \%$ level, $\mathrm{d}=$ first difference, $\mathrm{EC}=$ Error Correction term

Source-Calculated by author.

The estimated three cointegrating equations which were obtained from the system equations of the VECM are given below. All the three cointegrating equations are convergent but insignificantly tending towards equilibrium. The first cointegrating equation implies that the Asian export share has long run significant causalities with SAARC and ASEAN export shares to GCC respectively where the speed of adjustment is $42.7 \%$ per year. The second cointegrating equation also moves towards equilibrium insignificantly and its speed of adjustment is $63.7 \%$ per year. The equation states that the intra export share of GCC has long run causalities with SAARC and ASEAN export shares to GCC where the former is significant and the latter is insignificant. The third cointegrating equation is also approaching towards equilibrium insignificantly where the speed of adjustment was found as $2158 \%$ per year. The equation implies that the export concentration index of GCC has significant long run causalities with SAARC and ASEAN export shares to GCC respectively. The causality is negative with ASEAN but positive with SAARC in the first two equations and opposite in the third case.

$\mathrm{Z}_{\mathrm{tt}-1}=-0.427 \mathrm{XA}_{\mathrm{t}-1}-0.000436 \mathrm{GAX}_{\mathrm{t}-1}+0.00017 \mathrm{GSX}_{\mathrm{t}-1}-22.988$

$$
(-1.32) \quad(-6.24)^{*} \quad(3.63)^{*}
$$

$\mathrm{Z}_{2 \mathrm{t}-1}=-0.637 \mathrm{IX}_{\mathrm{t}-1}-9.4019 \mathrm{e}^{-05} \mathrm{GAX}_{\mathrm{t}-1}+3.071 \mathrm{e}^{-05} \mathrm{GSX}_{\mathrm{t}-1}-4.361$

$$
(-1.186) \quad(-2.18)^{*} \quad(1.03)
$$

$\mathrm{Z}_{3 \mathrm{t}-1}=-21.581$ XCIt-1 $+1.1246 \mathrm{e}^{-05} \mathrm{GAX}_{\mathrm{t}-1}-5.585 \mathrm{e}^{-06} \mathrm{GSX}_{\mathrm{t}-1}-0.769$

$$
(-1.835) \quad(4.18)^{*} \quad(-3.009)^{*}
$$

$*=$ significant at $5 \%$ level. $\mathrm{Z}_{\mathrm{it}-1}=$ cointegrating relation, $\mathrm{i}=1,2, \ldots \ldots \mathrm{n}$

The three cointegrating equations are shown in Figure 1 below.

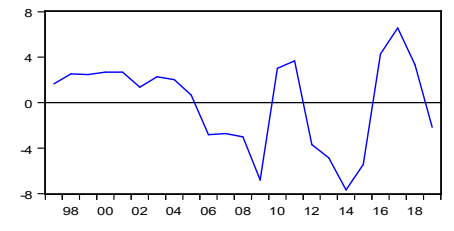

- Cointegrating relation 1

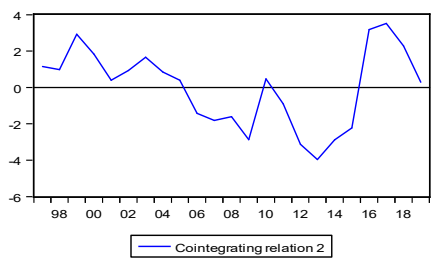

Figure 1. The Cointegrating equations

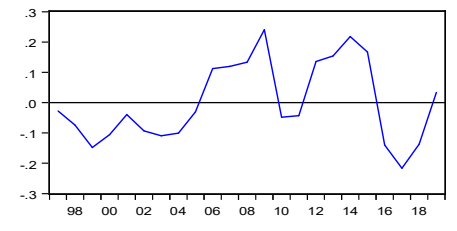

Cointegrating relation 3

Source: Plotted by author. 
The Wald test from the estimated system equations confirmed that there are short run causalities from export concentration index of GCC to intra export share of GCC, export share of ASEAN and SAARC with GCC respectively. There is short run causality from ASEAN export share with GCC to export share of Asia and from intra export share of GCC to export share of ASEAN with GCC. The short run causalities among those variables have been tabulated below.

Table 3. The Short run causalities

\begin{tabular}{|c|c|c|c|c|}
\hline $\begin{array}{c}\text { Short run causalities } \\
\text { from.... To........ }\end{array}$ & $\begin{array}{l}\text { Values of Chi-Square } \\
\text { (1) }\end{array}$ & $\mathrm{H} 0=$ no causality & Values of probability & $\begin{array}{c}\text { No Causality } \\
\text { accepted/rejected }\end{array}$ \\
\hline $\begin{array}{l}\text { From ASEAN export } \\
\text { share with GCC to } \\
\text { export share of Asia }\end{array}$ & 5.529 & $\mathrm{H} 0=$ no causality & 5.529 & rejected \\
\hline $\begin{array}{l}\text { From } \\
\text { concentration index of } \\
\text { GCC to intra export } \\
\text { share of GCC }\end{array}$ & 7.933 & $\mathrm{H} 0=$ no causality & 0.0043 & rejected \\
\hline $\begin{array}{l}\text { From intra export share } \\
\text { of GCC to export share } \\
\text { of ASEAN with GCC }\end{array}$ & 7.727 & $\mathrm{H} 0=$ no causality & 0.0054 & rejected \\
\hline $\begin{array}{l}\text { From export } \\
\text { concentration index of } \\
\text { GCC to export share of } \\
\text { ASEAN with GCC }\end{array}$ & 7.616 & $\mathrm{H} 0=$ no causality & 0.0058 & rejected \\
\hline $\begin{array}{l}\text { From export } \\
\text { concentration index of } \\
\text { GCC to export share } \\
\text { SAARC with GCC }\end{array}$ & 3.801 & $\mathrm{Ho}=$ no causality & 0.0512 & rejected \\
\hline
\end{tabular}

Source: Tabulated by author.

This VECM is nonstationary because there are two roots whose values are unity. The values of roots have been tabulated below.

Table 4. Values of roots

\begin{tabular}{|c|c|}
\hline Roots & Modulus \\
\hline 1.000000 & 1.000000 \\
\hline 1.000000 & 1.000000 \\
\hline-0.785936 & 0.785936 \\
\hline $0.393995-0.639225 \mathrm{i}$ & 0.750893 \\
\hline $0.393995+0.639225 \mathrm{i}$ & 0.750893 \\
\hline $0.596409-0.071245 \mathrm{i}$ & 0.600649 \\
\hline $0.596409+0.071245 \mathrm{i}$ & 0.600649 \\
\hline$-0.098989-0.574688 \mathrm{i}$ & 0.583151 \\
\hline$-0.098989+0.574688 \mathrm{i}$ & 0.583151 \\
\hline-0.581712 & 0.581712 \\
\hline
\end{tabular}

Source: Calculated by author.

Moreover, the VECM is stable because all the roots lie on or inside the unit circle which is plotted in Figure 2.

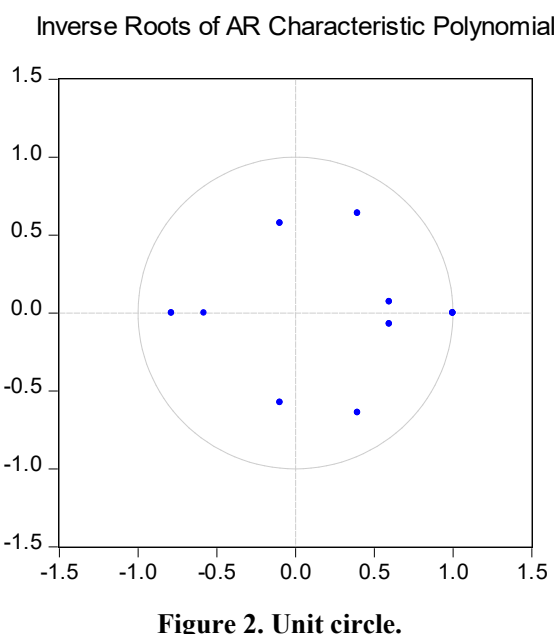

Source: Plotted by author. 
The impact of any shock to the respective variables measured by Cholesky one standard deviation innovations have been shown by the Impulse Response Functions whose explanations are given in the following Table 5.

Table 5. Analysis of Impulse Response Functions

\begin{tabular}{|l|c|c|}
\hline \multicolumn{1}{|c|}{ Responses of ......... to ............... } & $\begin{array}{c}\text { Reached equilibrium at } \\
\ldots \ldots . \text { years }\end{array}$ & $\begin{array}{c}\text { Then moves } \\
\text { convergent/divergent }\end{array}$ \\
\hline Response of export share of Asia to intra export share of GCC & Not reached any time & Divergent \\
\hline Response of export share of Asia to export concentration index of GCC & Not reached any time & divergent \\
\hline Response of export share of Asia to export share ASEAN with GCC & 3 years & divergent \\
\hline Response of export share of Asia to export share of SAARC with GCC & Not reached any time & Divergent \\
\hline Response of intra export share of GCC to export share ASEAN with GCC & 4years & Divergent \\
\hline Response of intra export share of GCC to export concentration index of GCC & $3,5,8$ years & Divergent \\
\hline Response of intra export share of GCC to export share ASEAN with GCC & 6,10 years & divergent \\
\hline Response of intra export share of GCC to export share SAARC with GCC & 5 years & divergent \\
\hline Response of export concentration index of GCC to export share of Asia & 2 years & divergent \\
\hline Response of export concentration index of GCC to intra export share of GCC & Not reached any time & convergent \\
\hline Response of export concentration index of GCC to export share ASEAN with GCC & 7 years & divergent \\
\hline Response of export concentration index of GCC to export share SAARC with GCC & 8 years & divergent \\
\hline Response of export share ASEAN with GCC to export share of Asia & 7 years & divergent \\
\hline Response of export share ASEAN with GCC to intra export share of GCC & Not reached any time & divergent \\
\hline Response of export share ASEAN with GCC to export concentration index of GCC & 5 years & divergent \\
\hline Response of export share ASEAN with GCC to export share SAARC with GCC & Not reached any time & divergent \\
\hline Response of export share SAARC with GCC to export share of Asia & 7,8 years & divergent \\
\hline Response of export share SAARC with GCC to intra export share of GCC & Not reached any time & divergent \\
\hline Response of export share SAARC with GCC to export concentration index of GCC & Not reached any time & \\
\hline Response of export share SAARC with GCC to export share ASEAN with GCC & Not reached any time & \\
\hline
\end{tabular}

Source: Prepared by author.

All these shocks have been exposed in the Figure 3.
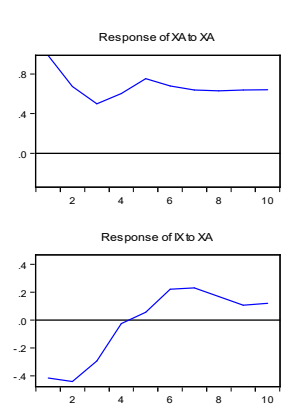

Response of $X \mathrm{Cl} 1 \mathrm{x} \times$

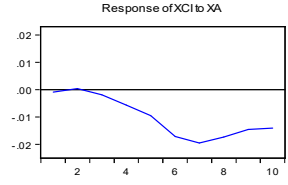

Response of GAX to XA

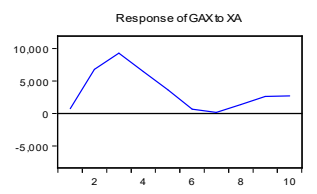

Response of GSX to XA

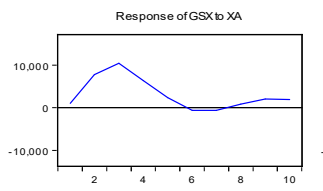

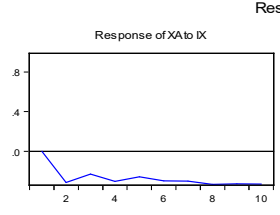

Response of $x$ tio $x$

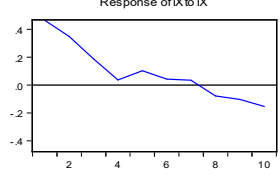

Response of $\times C$ Ito $1 \times$

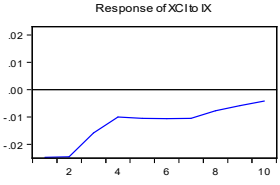

Response of GAXto DX

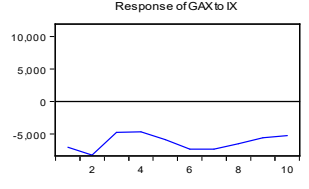

Response of GSXto 1

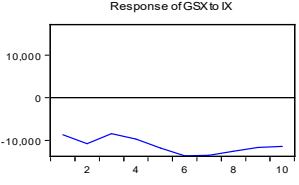

Response to Cholesky One S.D. (d.f. adjusted) Innovations

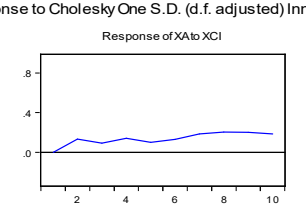

Response of $\mathrm{Xto} \times \mathrm{XCI}$

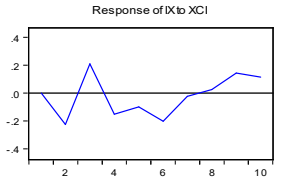

Response of $x$ C1 $10 \times 1$

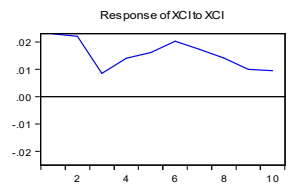

Response of $G A \times D \times C$
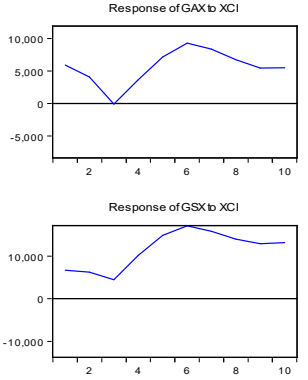

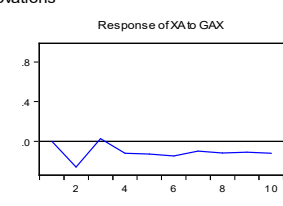

Response ofIX to GAX

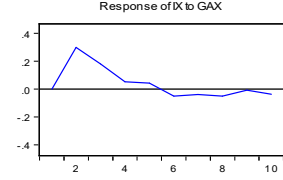

Response of $\mathrm{XC1}$ to GAX
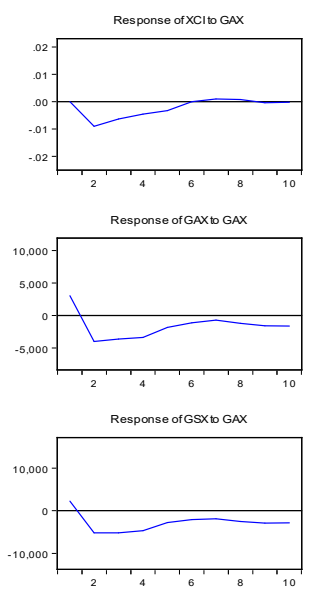

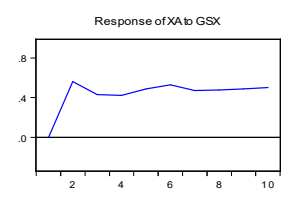

Response of IX to GSX

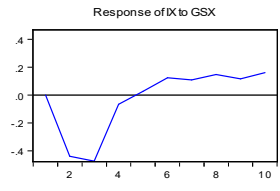

Response ofXCIt GSX
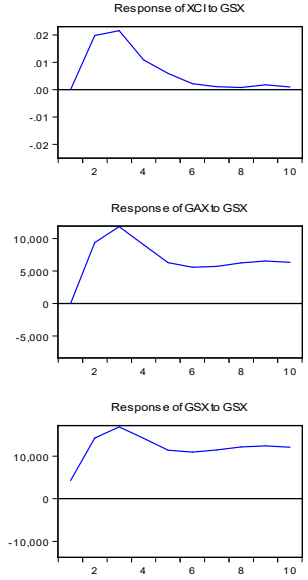

Figure 3. Impulse Response Functions

Source: Plotted by author.

Johansen unrestricted cointegration rank test in linear deterministic trend among first difference series of import share of Asia, intra-import share of GCC, import concentration index of GCC, export share of SAARC and ASEAN with GCC during 1995 -2019 revealed that Trace and Max Eigen statistic showed three cointegrating equations among them which are significant. It implies that the variables are associated in the long run i.e., Asian import share is influenced by the intra import and inter trade of GCC with ASEAN and SAARC in the long run. The values of Trace statistic, Max Eigen statistic, Critical Value and their probabilities have been given in the Table 6 . 
Table 6. Johansen Cointegration test

\begin{tabular}{|c|c|c|c|c|}
\hline $\begin{array}{l}\text { Hypothesized } \\
\text { No. of CE(s) }\end{array}$ & Eigenvalue & $\begin{array}{c}\text { Trace } \\
\text { Statistic }\end{array}$ & $\begin{array}{c}0.05 \\
\text { Critical Value }\end{array}$ & Probability** \\
\hline None $*$ & 0.830930 & 106.6624 & 69.81889 & 0.0000 \\
\hline At most $1 *$ & 0.725246 & 65.78122 & 47.85613 & 0.0005 \\
\hline At most $2 *$ & 0.620734 & 36.06798 & 29.79707 & 0.0083 \\
\hline At most 3 & 0.376510 & 13.76907 & 15.49471 & 0.0895 \\
\hline At most 4 & 0.118590 & 2.903337 & 3.841466 & 0.0884 \\
\hline & & $\begin{array}{c}\text { Max-Eigen } \\
\text { Statistic }\end{array}$ & & \\
\hline None $*$ & 0.830930 & 40.88115 & 33.87687 & 0.0062 \\
\hline At most $1 *$ & 0.725246 & 29.71324 & 27.58434 & 0.0262 \\
\hline At most $2 *$ & 0.620734 & 22.29891 & 21.13162 & 0.0341 \\
\hline At most 3 & 0.376510 & 10.86573 & 14.26460 & 0.1610 \\
\hline At most 4 & 0.118590 & 2.903337 & 3.841466 & 0.0884 \\
\hline
\end{tabular}

* denotes rejection of the hypothesis at the 0.05 level, **MacKinnon-Haug-Michelis (1999) p-values, $\mathrm{n}=23$ (after adjustment).

Source: Calculated by author.

The estimated first equation states that the change of the import share of Asia is insignificantly negatively affected by incremental intra import share of GCC and incremental import share of SAARC with GCC of the previous period, and significantly negatively related with import concentration index of GCC of the previous period and insignificantly positively influenced by incremental import share of ASEAN with GCC of the previous period respectively. The values of $\mathrm{R}^{2}$ and $\mathrm{F}$ are high. The first two error correction terms are converging insignificantly and the third error term is significantly diverging. The estimated third equation states that the incremental intra import share of GCC is significantly negatively related with incremental import concentration index of GCC, and incremental import share of SAARC with GCC of earlier period. It is also significantly positively related with incremental import share of GCC and insignificantly positively related with import share of ASEAN with GCC of the previous period. Here both $\mathrm{R}^{2}$ and $\mathrm{F}$ are high. The first Error correction and third error correction are divergent where the first is insignificant and the third is significant. The second error correction term is convergent and significant. The third estimated equation implies that the incremental import concentration index of GCC is insignificantly affected by incremental intra import share of GCC, import share of ASEAN and SAARC with GCC of previous periods respectively and insignificantly positively related with incremental import share of Asia of the previous period. Here $\mathrm{R}^{2}$ and $\mathrm{F}$ are high. The first error correction term is divergent and significant, second error correction term is divergent and insignificant and the third error correction term is convergent and significant. The estimated fourth equation states that the incremental import share of ASEAN with GCC is insignificantly negatively related with incremental import share of Asia, intra import share of GCC, import concentration index of GCC and import share of SAARC with GCC of earlier periods respectively. Here $\mathrm{R}^{2}$ and $\mathrm{F}$ are high. The first and second error correction terms are divergent and insignificant but the third error correction term is convergent and insignificant. The estimated fourth equation implies that the incremental import share of SAARC with GCC is negatively influenced by incremental intra import share of GCC and import concentration index of GCC of earlier periods both of which are insignificant. It is positively related with import share of Asia and import share of ASEAN with GCC of the previous period respectively. All of them are insignificant. Here $\mathrm{R}^{2}$ and $\mathrm{F}$ are low. The first and second error correction terms are divergent and insignificant and third one is convergent and insignificant.

Table 7. The estimated VECM

\begin{tabular}{|l|c|c|c|c|c|}
\hline & $\mathrm{dIA}_{\mathrm{t}}$ & $\mathrm{dIM}_{\mathrm{t}}$ & $\mathrm{dICI}_{\mathrm{t}}$ & $\mathrm{dGAM}_{\mathrm{t}}$ & $\mathrm{dGSM}_{\mathrm{t}}$ \\
\hline $\mathrm{EC} 1$ & -0.128165 & 0.081739 & 0.001210 & 7.169111 & 252.6360 \\
\hline $\mathrm{t}$ values & {$[-1.61125]$} & {$[1.32007]$} & {$[3.05133]$} & {$[0.03626]$} & {$[0.69684]$} \\
\hline $\mathrm{EC} 2$ & -0.570733 & -1.395237 & 0.002901 & 941.7710 & 2.557986 \\
\hline $\mathrm{t}$ values & {$[-1.61515]$} & {$[-5.07225]^{*}$} & {$[1.64673]$} & {$[1.07230]$} & {$[0.00159]$} \\
\hline $\mathrm{EC} 3$ & 146.4005 & 166.9133 & -0.734477 & -12702.91 & -40090.33 \\
\hline $\mathrm{t}$ values & {$[3.27669]^{*}$} & {$[4.79906]^{*}$} & {$[-3.29787]^{*}$} & {$[-0.11439]$} & {$[-0.19687]$} \\
\hline $\mathrm{dIA}_{\mathrm{t}-1}$ & 0.256579 & 0.386814 & 0.000157 & -439.8473 & 817.7822 \\
\hline $\mathrm{t}$ values & {$[1.44015]$} & {$[2.78908]^{*}$} & {$[0.17690]$} & {$[-0.99330]$} & {$[1.00709]$} \\
\hline \multicolumn{1}{|c|}{$\mathrm{dIM}_{\mathrm{t}-1}$} & -0.053134 & 0.239366 & -0.001971 & -207.1812 & -1260.243 \\
\hline \multicolumn{1}{|c|}{$\mathrm{t}$ values } & {$[-0.23179]$} & {$[1.34142]$} & {$[-1.72506]$} & {$[-0.36364]$} & {$[-1.20623]$} \\
\hline \multicolumn{1}{|c|}{$\mathrm{dICI}_{\mathrm{t}-1}$} & -198.9101 & -99.48993 & -0.046565 & -88015.13 & -106310.6 \\
\hline $\mathrm{t}_{\text {values }}$ & {$[-4.62275]^{*}$} & {$[-2.97026]^{*}$} & {$[-0.21710]$} & {$[-0.82298]$} & {$[-0.54208]$} \\
\hline $\mathrm{dGAM}_{\mathrm{t}-1}$ & $9.84 \mathrm{E}-05$ & 0.000140 & $-1.51 \mathrm{E}-07$ & 0.454661 & 0.313026 \\
\hline $\mathrm{t}$ values & {$[1.04114]$} & {$[1.89844]$} & {$[-0.32021]$} & {$[1.93638]$} & {$[0.72700]$} \\
\hline $\mathrm{dGSM}_{\mathrm{t}-1}$ & $-1.02 \mathrm{E}-05$ & -0.000134 & $-4.99 \mathrm{E}-07$ & -0.333793 & -0.068797 \\
\hline
\end{tabular}


Table 7 (cont). The estimated VECM

\begin{tabular}{|l|c|c|c|c|c|}
\hline $\mathrm{t}$ values & {$[-0.13926]$} & {$[-2.34133]^{*}$} & {$[-1.36158]$} & {$[-1.82830]$} & {$[-0.20549]$} \\
\hline \multicolumn{1}{|c|}{$\mathrm{C}$} & 0.441492 & 0.125657 & 0.002765 & 1515.902 & 1468.955 \\
\hline $\mathrm{t}$ values & {$[1.92808]$} & {$[0.70496]$} & {$[2.42252]^{*}$} & {$[2.66357]^{*}$} & {$[1.40752]$} \\
\hline R-squared & 0.727350 & 0.773915 & 0.633249 & 0.669747 & 0.335206 \\
\hline F-statistic & 4.668477 & 5.990459 & 3.021633 & 3.548974 & 0.882396 \\
\hline Akaike AIC & 2.763923 & 2.263006 & -7.838852 & 18.40036 & 19.61311 \\
\hline Schwarz SC & 3.208247 & 2.707330 & -7.394528 & 18.84468 & 20.05744 \\
\hline
\end{tabular}

$\mathrm{n}=23$ (after adjustment), EC=Error Correction term, $\mathrm{d}=$ first difference, ${ }^{*}=$ significant at $5 \%$ level. Source: Calculated by author.

The estimated three cointegrating equations are shown below:

$\mathrm{Z}_{1 \mathrm{t}-1}=-0.128 \mathrm{IA}_{\mathrm{t}-1}-0.00293 \mathrm{GAM}_{\mathrm{t}-1}+0.001579 \mathrm{GSM}_{\mathrm{t}-1}-19.474$

$$
(-1.61) \quad(-5.13)^{*} \quad(4.22)^{*}
$$

$\mathrm{Z}_{2 \mathrm{t}-1}=-1.395 \mathrm{IM}_{\mathrm{t}-1}-0.000984 \mathrm{GAM}_{\mathrm{t}-1}+0.000612 \mathrm{GSM}_{\mathrm{t}-1}-8.710$

$$
(-5.07)^{*} \quad(-5.58)^{*} \quad(5.31)^{*}
$$

$\mathrm{Z}_{3 \mathrm{t}-1}=-0.7344 \mathrm{ICI}_{\mathrm{t}-1}-8.195 \mathrm{e}^{-06} \mathrm{GAM}_{\mathrm{t}-1}+4.8519 \mathrm{e}^{-06} \mathrm{GSM}_{\mathrm{t}-1}-0.0515$

$$
(-3.29)^{*} \quad(5.98)^{*}
$$

$*=$ significant at $5 \%$ level

The estimated first cointegrating equation implies that the import share of Asia has long run causalities with the import shares of ASEAN and SAARC with GCC respectively where both are significant but the cointegrating equation has been approaching towards equilibrium insignificant in which the speed of adjustment is found as $12.8 \%$ per year. The second cointegrating equation states that the intra import share of GCC has long run causalities with the import shares of ASEAN and SAARC with GCC respectively where both are significant but the cointegrating equation has been converging and reached towards equilibrium significantly. The speed of adjustment is seen as $139.5 \%$ per year. The third cointegrating equation implies that the import concentration index of GCC has long run causalities with the import shares of ASEAN and SAARC with GCC respectively where both are significant and the equation has been converging significantly where the speed of adjustment is $73.44 \%$ per year. In Figure 4, the three equations have been depicted neatly. The causality with import share of ASEAN with GCC is negative and is positive with SAARC.
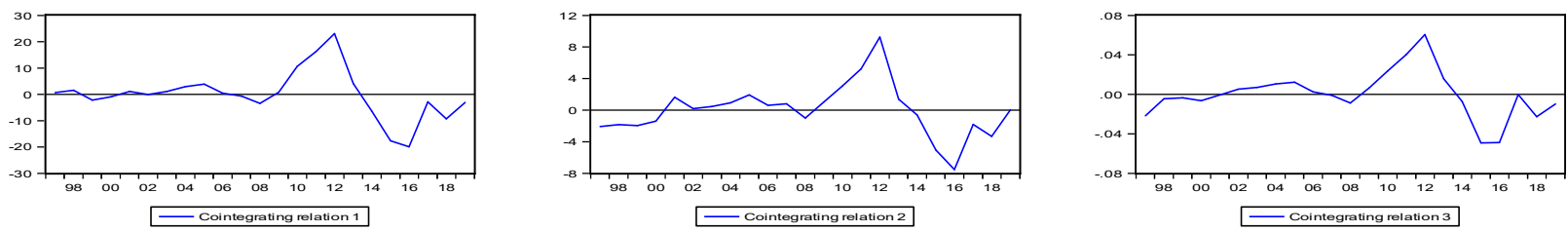

Figure 4. The Cointegrating relations

Source: Plotted by author

The Wald test of the estimated system equation of VECM revealed that the intra import share of GCC has short run causalities with import share of Asia, import concentration index of GCC and import share of ASEAN with GCC respectively. The import concentration index has short run causality with the import share of Asia. The import share of SAARC with GCC has short run causality with import share of ASEAN with GCC. These short run causalities

\begin{tabular}{|c|c|c|c|c|}
\hline Short run causalities from.... To........ & $\begin{array}{l}\text { Values of Chi- } \\
\text { Square (1) }\end{array}$ & $\mathrm{H} 0=$ no causality & $\begin{array}{l}\text { Values of } \\
\text { probability }\end{array}$ & $\begin{array}{ll}\text { No } & \text { Causality } \\
\text { accepted/rejected } & \\
\end{array}$ \\
\hline $\begin{array}{l}\text { Import concentration index of GCC to } \\
\text { import share of Asia }\end{array}$ & 21.369 & $\mathrm{H} 0=$ no causality & 0.0000 & rejected \\
\hline $\begin{array}{l}\text { Import share of Asia to intra import } \\
\text { share of GCC }\end{array}$ & 7.778 & $\mathrm{H} 0=$ no causality & 0.0053 & rejected \\
\hline $\begin{array}{l}\text { Import concentration index of GCC to } \\
\text { intra import share of GCC }\end{array}$ & 8.8224 & $\mathrm{H} 0=$ no causality & 0.0030 & rejected \\
\hline $\begin{array}{l}\text { Import share of ASEAN with GCC to } \\
\text { intra import share of GCC }\end{array}$ & 3.604 & $\mathrm{H} 0=$ no causality & 0.0576 & rejected \\
\hline $\begin{array}{l}\text { Import share of SAARC with GCC to } \\
\text { intra import share of GCC }\end{array}$ & 5.481 & $\mathrm{Ho}=$ no causality & 0.0192 & rejected \\
\hline $\begin{array}{l}\text { Import share of SAARC with GCC to } \\
\text { import share of ASEAN with GCC }\end{array}$ & 3.342 & $\mathrm{H} 0=$ no causality & 0.067 & rejected \\
\hline
\end{tabular}
have been arranged in the Table 8 .

Table 8. The Short run causalities

Source: Tabulated by author. 
There are two roots in the estimated VECM which are equal to unity so that the model is non-stationary. The values of all roots are given in the Table 9.

Table 9. Values of Roots

\begin{tabular}{|c|c|}
\hline roots & modulus \\
\hline 1.000000 & 1.000000 \\
\hline 1.000000 & 1.000000 \\
\hline $0.004500-0.831651 \mathrm{i}$ & 0.831663 \\
\hline $0.004500+0.831651 \mathrm{i}$ & 0.831663 \\
\hline 0.719729 & 0.719729 \\
\hline $0.378617-0.587522 \mathrm{i}$ & 0.698951 \\
\hline $0.378617+0.587522 \mathrm{i}$ & 0.698951 \\
\hline$-0.546672-0.365561 \mathrm{i}$ & 0.657636 \\
\hline$-0.546672+0.365561 \mathrm{i}$ & 0.657636 \\
\hline 0.546950 & 0.546950 \\
\hline
\end{tabular}

Source- Calculated by author.

All the roots lie on or inside the unit circle for which it is a stable model. The unit circle and roots are plotted in Figure 5.

Inverse Roots of AR Characteristic Polynomial

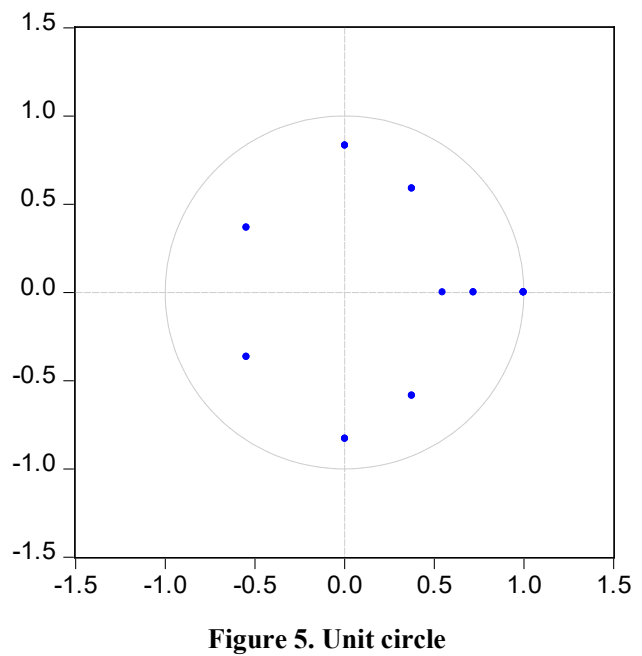

Source: Plotted by author.

The impulse response functions measured by Cholesky one standard deviation innovation from any shock to the respective variables have been described below in a tabulated form and is given below in Table 10 .

Table 10. Analytics of Impulse Response Functions

\begin{tabular}{|c|c|c|c|c|}
\hline Responses of. & \multicolumn{2}{|c|}{ Reached equilibrium at .......years } & \multicolumn{2}{|c|}{ Then moves convergent/divergent } \\
\hline Response of import share of Asia to intra import share of GCC & \multicolumn{2}{|c|}{ Not reached equilibrium any time } & \multicolumn{2}{|c|}{ Divergent } \\
\hline Response of import share of Asia to import concentration of GCC & \multicolumn{2}{|c|}{ Not reached equilibrium any time } & \multicolumn{2}{|c|}{ Divergent } \\
\hline Response of import share of Asia to import share of ASEAN with GCC & & $3,5,9$ years & \multirow{2}{*}{\multicolumn{2}{|c|}{ divergent }} \\
\hline Response of import share of Asia to import share of SAARC with GCC & \multicolumn{2}{|c|}{ Not reached equilibrium any time } & \multirow{2}{*}{\multicolumn{2}{|c|}{$\begin{array}{l}\text { divergent } \\
\text { Divergent }\end{array}$}} \\
\hline Response of intra import share of GCC to import share of Asia & \multicolumn{2}{|c|}{ Not reached equilibrium any time } & & \\
\hline Response of intra import share of GCC to import concentration of GCC & \multicolumn{2}{|r|}{5.5 years } & \multicolumn{2}{|c|}{ Divergent } \\
\hline \multicolumn{2}{|l|}{ Response of intra import share of GCC to import share of ASEAN with GCC } & \multicolumn{2}{|c|}{$\begin{array}{c}\text { Not reached equilibrium any } \\
\text { time }\end{array}$} & Divergent \\
\hline \multicolumn{2}{|l|}{ Response of intra import share of GCC to import share of SAARC with GCC } & \multicolumn{2}{|c|}{$3,4.5$ years } & divergent \\
\hline \multicolumn{2}{|l|}{ Response of import concentration index of GCC to import share of Asia } & \multicolumn{2}{|c|}{$\begin{array}{l}\text { Not reached equilibrium any } \\
\text { time }\end{array}$} & divergent \\
\hline \multicolumn{2}{|l|}{ Response of import concentration index of GCC to intra import share of GCC } & \multicolumn{2}{|c|}{3.7 years } & divergent \\
\hline \multicolumn{2}{|l|}{$\begin{array}{l}\text { Response of import concentration index of GCC to import share of ASEAN with } \\
\text { GCC }\end{array}$} & \multicolumn{2}{|c|}{$\begin{array}{l}\text { Not reached equilibrium any } \\
\text { time }\end{array}$} & divergent \\
\hline \multicolumn{2}{|l|}{$\begin{array}{l}\text { Response of import concentration index of GCC to import share of SAARC with } \\
\text { GCC }\end{array}$} & \multicolumn{2}{|c|}{3.5 years } & divergent \\
\hline \multicolumn{2}{|l|}{ Response of import share of ASEAN with GCC to import share of Asia } & \multicolumn{2}{|l|}{3 years } & divergent \\
\hline \multirow{2}{*}{\multicolumn{2}{|c|}{$\begin{array}{l}\text { Response of import share of ASEAN with GCC to intra import share of GCC } \\
\text { Response of import share of ASEAN with GCC to import concentration index of } \\
\text { GCC }\end{array}$}} & \multirow{2}{*}{\multicolumn{2}{|c|}{$\begin{array}{l}4 \text { years } \\
2 \text { years }\end{array}$}} & divergent \\
\hline & & & & divergent \\
\hline
\end{tabular}


Table 10 (cont). Analytics of Impulse Response Functions

\begin{tabular}{|l|c|c|}
\hline $\begin{array}{l}\text { Response of import share of ASEAN with GCC to import share of SAARC with } \\
\text { GCC }\end{array}$ & $\begin{array}{c}\text { Not reached equilibrium any } \\
\text { time }\end{array}$ & divergent \\
\hline Response of import share of SAARC with GCC to import share of Asia & $\begin{array}{c}\text { Not reached equilibrium any } \\
\text { time }\end{array}$ & divergent \\
\hline Response of import share of SAARC with GCC to intra import share of GCC & years & divergent \\
\hline $\begin{array}{l}\text { Response of import share of SAARC with GCC to import concentration index of } \\
\text { GCC }\end{array}$ & $\begin{array}{c}\text { Not reached equilibrium any } \\
\text { time }\end{array}$ & divergent \\
\hline $\begin{array}{l}\text { Response of import share of SAARC with GCC to import share of ASEAN with } \\
\text { GCC }\end{array}$ & $\begin{array}{c}\text { Not reached equilibrium any } \\
\text { time }\end{array}$ & divergent \\
\hline
\end{tabular}

Source: Tabulated by author.

All the responses from the shocks to the variables are plotted in the impulse response functions in Figure 6.

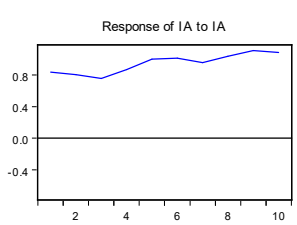

Response of IM to IA

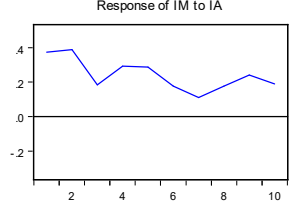

Response of ICI to IA

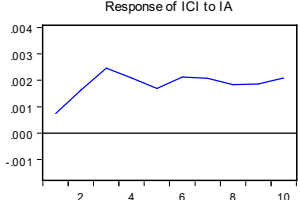

Response of GAM to IA

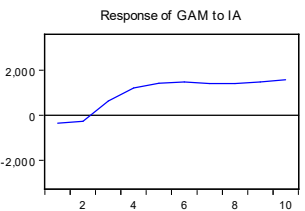

Response of GSM to IA
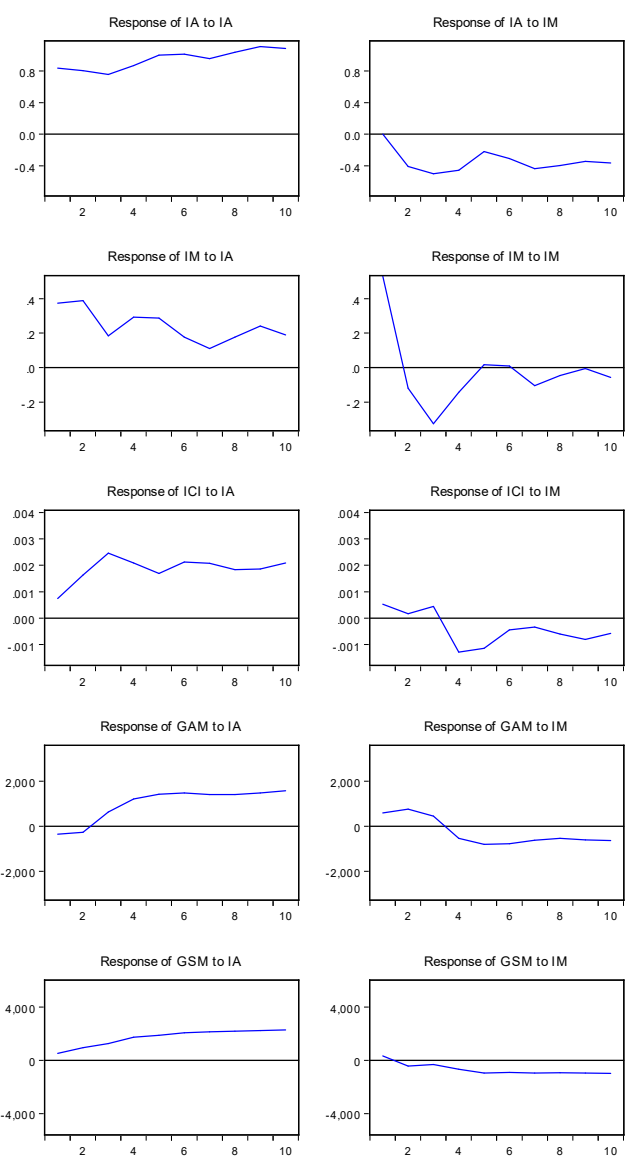

Response to Cholesky One S.D. (d.f. adjusted) Innovation
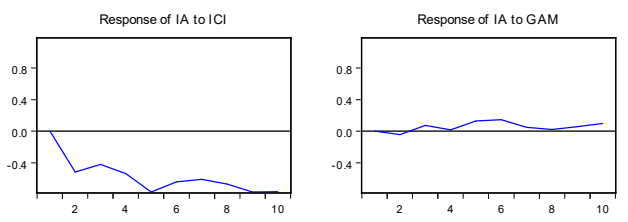

Response of IM to IC

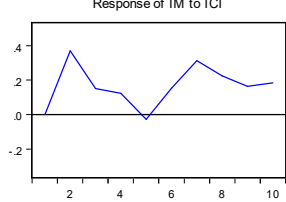

Response of IM to GAM

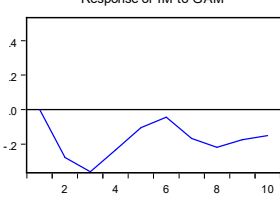

Response of ICI to ICI

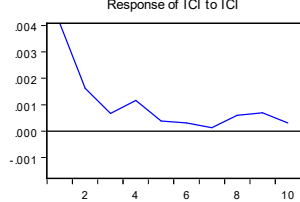

Response of ICI to GAM

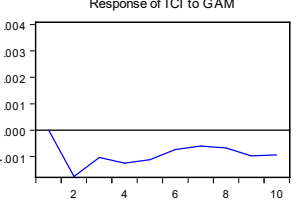

Response of GAM to ICI
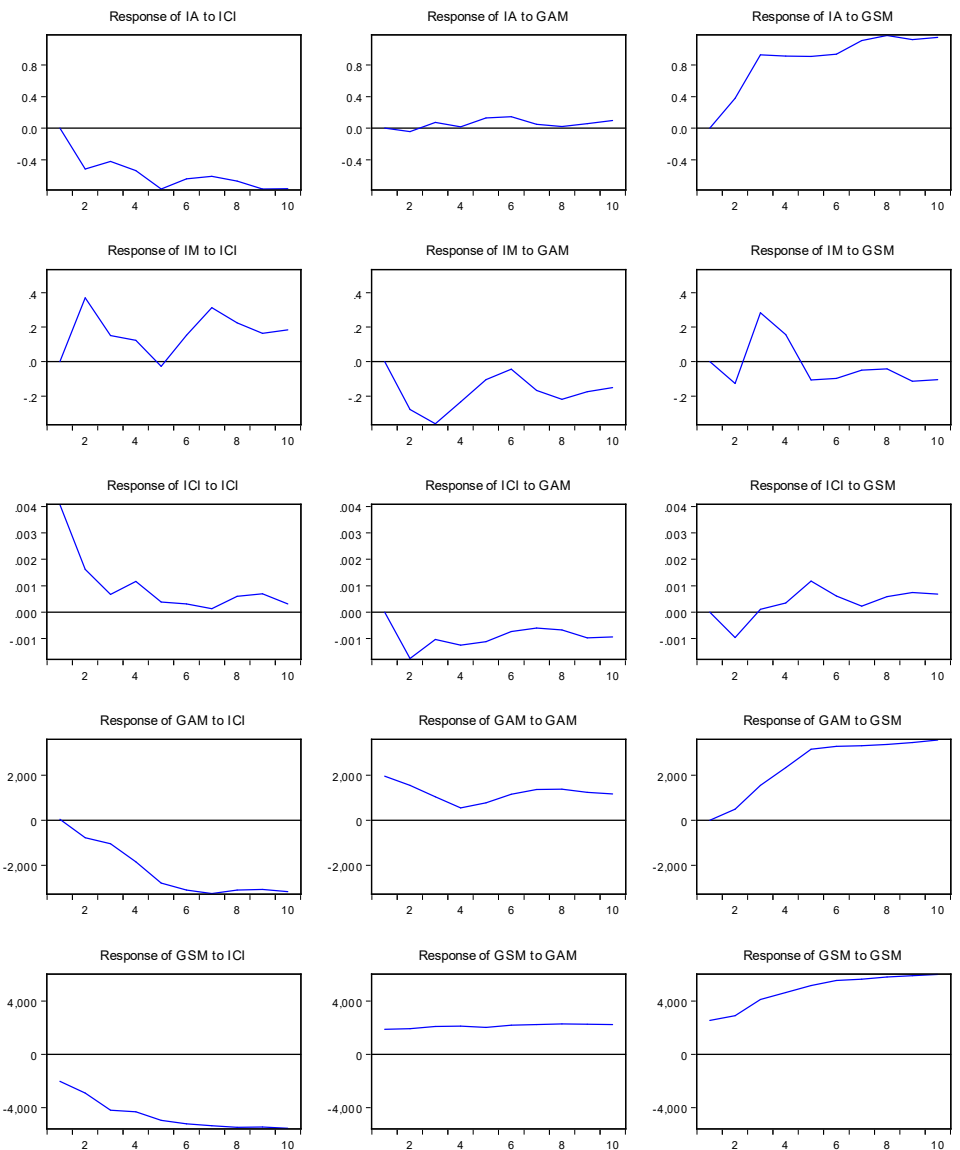

Figure 6. The Impulse Response Functions.

Source: Plotted by author.

\section{Impact of GCC on Asian regional development}

Johansen unrestricted cointegration rank test among the first difference series of Asian GDP, sum of intra export and import shares of GCC, sum of export and import shares of ASEAN with GCC, and sum of export and import shares of SAARC with GCC during 1995-2019 revealed that there is one cointegrating equation in Trace statistic only which is shown in the Table 11 which implies that the variables have long run association among themselves i.e., Asian GDP is influenced by the intra trade of GCC and inter trade of GCC with SAARC and ASEAN in the long run.

Table 11. Results of cointegration test

\begin{tabular}{|c|c|c|c|c|}
\hline $\begin{array}{c}\text { Hypothesized } \\
\text { No. of CE(s) }\end{array}$ & Eigenvalue & $\begin{array}{c}\text { Trace } \\
\text { Statistic }\end{array}$ & $\begin{array}{c}0.05 \\
\text { Critical Value }\end{array}$ & Probability** \\
\hline None & 0.632322 & 49.86991 & 47.85613 & 0.0319 \\
\hline At most 1 & 0.499734 & 26.85730 & 29.79707 & 0.1052 \\
\hline At most 2 & 0.283448 & 10.92716 & 15.49471 & 0.2160 \\
\hline At most 3 & 0.132196 & 3.261152 & 3.841466 & 0.0709 \\
\hline None & 0.632322 & Max-Eigen Statistic & & 0.1729 \\
\hline
\end{tabular}


Table 11 (cont.). Results of cointegration test

\begin{tabular}{|c|c|c|c|c|}
\hline At most 1 & 0.499734 & 15.93014 & 21.13162 & 0.2290 \\
\hline At most 2 & 0.283448 & 7.666010 & 14.26460 & 0.4137 \\
\hline At most 3 & 0.132196 & 3.261152 & 3.841466 & 0.0709 \\
\hline
\end{tabular}

* denotes rejection of the hypothesis at the 0.05 level, **MacKinnon-Haug-Michelis (1999) p-values, N=23 (after adjustment).

Source: Calculated by author.

The estimated VECM is given below. The first estimated equation of VECM states that the incremental GDP of Asia is insignificantly positively related with the incremental sum of intra export and import shares of GCC and the incremental sum of export and import shares of SAARC with GCC and significantly negatively related with the incremental sum of export and import shares of ASEAN with GCC of the previous periods. Here $\mathrm{R}^{2}$ and $\mathrm{F}$ are high. The error correction term is insignificant but convergent. The estimated second equation implies that the change of sum of intra export and import shares of GCC are significantly negatively related with the incremental sum of export and import shares of SAARC with GCC of the earlier period and are significantly positively influenced by the incremental sum of export and import shares of ASEAN with GCC of the previous periods and is insignificantly positively related with incremental GDP of Asia of the previous period. The values of $\mathrm{R}^{2}$ and $\mathrm{F}$ are quite high. The error correction term is divergent and significant. The estimated third equation states that the incremental sum of export and import shares of ASEAN with GCC is insignificantly negatively related with the incremental sum of intra export and import shares of GCC of earlier period and is insignificantly positively related with the incremental GDP share of Asia of previous period. Here $\mathrm{R}^{2}$ and $\mathrm{F}$ are low. The error correction term is divergent and insignificant. The estimated fourth equation of VECM implies that the change of sum of export and import shares of SAARC with GCC is insignificantly negatively affected by the changes of intra export and import shares of GCC of earlier period and the incremental sum of export and import shares of ASEAN with GCC of the previous period respectively and is insignificantly positively influenced by the change of GDP of Asia of the previous period. In this case the values of $\mathrm{R}^{2}$ and $\mathrm{F}$ are quite high.

Table 12. The Estimated VECM

\begin{tabular}{|c|c|c|c|c|}
\hline & $\mathrm{d}(\mathrm{GDPA})_{\mathrm{t}}$ & $\mathrm{d}(\mathrm{IX}+\mathrm{IM})_{\mathrm{t}}$ & $\mathrm{d}(\mathrm{GAM}+\mathrm{GAX})_{\mathrm{t}}$ & $\mathrm{d}(\mathrm{GSM}+\mathrm{GSX})_{\mathrm{t}}$ \\
\hline $\mathrm{EC}$ & -0.001448 & $2.76 \mathrm{E}-06$ & 0.042098 & 0.024749 \\
\hline $\mathrm{t}$ values & {$[-0.96450]$} & {$[2.57424]^{*}$} & {$[1.52873]$} & {$[0.80561]$} \\
\hline $\mathrm{d}\left(\mathrm{GDPA}_{\mathrm{t}-1}\right)$ & 0.798370 & 0.000378 & 4.431054 & 4.518884 \\
\hline t values & {$[2.83044]^{*}$} & {$[1.87456]$} & {$[0.85619]$} & {$[0.78269]$} \\
\hline $\mathrm{d}\left(\mathrm{IX}_{\mathrm{t}-1}+\mathrm{IM}_{\mathrm{t}-1}\right)$ & 64.08097 & -0.653371 & -870.2411 & -2406.961 \\
\hline $\mathrm{t}$ values & {$[0.33888]$} & {$[-4.83869]^{*}$} & {$[-0.25083]$} & {$[-0.62187]$} \\
\hline $\mathrm{d}\left(\mathrm{GAM}_{\mathrm{t}-1}+\mathrm{GAX}_{\mathrm{t}-1}\right)$ & -0.098756 & $9.70 \mathrm{E}-05$ & -0.305114 & -1.166691 \\
\hline $\mathrm{t}$ values & {$[-2.53232]^{*}$} & {$[3.48334]^{*}$} & {$[-0.42641]$} & {$[-1.46157]$} \\
\hline $\mathrm{d}\left(\mathrm{GSM}_{\mathrm{t}-1}+\mathrm{GSX}_{\mathrm{t}-1}\right)$ & 0.058127 & -0.000106 & 0.242159 & 0.962519 \\
\hline t values & [ 1.52694$]$ & {$[-3.88840]^{*}$} & {$[0.34671]$} & {$[1.23529]$} \\
\hline $\mathrm{C}$ & 422.7615 & 0.336717 & -311.7355 & 1648.960 \\
\hline $\mathrm{t}$ values & {$[1.43785]$} & {$[1.60371]$} & {$[-0.05779]$} & [0.27399] \\
\hline R-squared & 0.541132 & 0.708524 & 0.299875 & 0.354470 \\
\hline F-statistic & 4.009531 & 8.264757 & 1.456276 & 1.866990 \\
\hline Akaike AIC & 16.68388 & 2.194892 & 22.50292 & 22.72167 \\
\hline Schwarz SC & 16.98010 & 2.491108 & 22.79914 & 23.01789 \\
\hline
\end{tabular}

$\mathrm{n}=23$ (after adjustment), $*$ =significant at $5 \%$ level, $\mathrm{EC}=$ error correction term, $\mathrm{d}=$ first difference.

Source: Calculated by author.

The estimated cointegrating equation is as follows:

$\mathrm{Z}_{\mathrm{t}-1}=-0.001448 \mathrm{GDPA}_{\mathrm{t}-1}-57724.67\left(\mathrm{IX}_{\mathrm{t}-1}+\mathrm{IM}_{\mathrm{t}-1}\right)-15.827\left(\mathrm{GAM}_{\mathrm{t}-1}+\mathrm{GAX}_{\mathrm{t}-1}\right)+10.91\left(\mathrm{GSM}_{\mathrm{t}-1}+\mathrm{GSX}_{\mathrm{t}-1}\right)$

$$
\text { [ }-0.964 \text { ] }
$$

$[-2.560]^{*}$

$[-3.911]^{*}$

[3.981]*

\section{$+1219108.33006$}

The cointegrating equation has been approaching towards equilibrium with the speed of adjustment of $0.1448 \%$ per year which is insignificant. It implies that the GDP of Asia has long run causalities with the sum of intra export and import shares of GCC, the sum of export and import shares of ASEAN with GCC and the sum of export and import shares of SAARC with GCC where causal relations are significant. The first and second causal relations are negative and the third one is positive. 
It is clearly seen in the Figure 7.

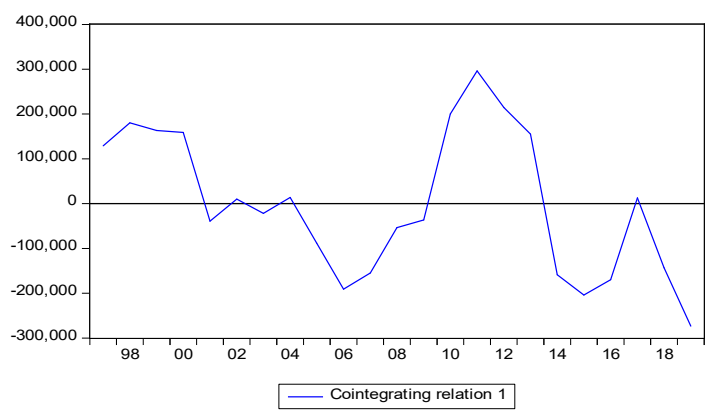

Figure 7. The Cointegrating equation

Source: Plotted by author.

The Wald test of the estimated system equations of the estimated VECM revealed that there is a short run causality from sum of export and import shares of ASEAN shares with GCC to the GDP of Asia and there are short run causalities from the sum of export and import shares of ASEAN and SAARC shares with GCC to sum of intra export and import shares of GCC during 1995-2019.In Table 13, the causalities are noted briefly.

Table13. The Short run causalities

\begin{tabular}{|c|c|c|c|c|c|}
\hline $\begin{array}{l}\text { Short run causalities from.... } \\
\text { To........ }\end{array}$ & $\begin{array}{l}\text { Values of Chi- } \\
\text { Square (1) }\end{array}$ & $\mathrm{H} 0=$ no causality & $\begin{array}{l}\text { Values of } \\
\text { probability }\end{array}$ & $\begin{array}{c}\text { No Causality } \\
\text { accepted/rejected }\end{array}$ & Causal relation \\
\hline $\begin{array}{l}\text { From sum of export and import } \\
\text { shares of ASEAN shares with } \\
\text { GCC to the GDP of Asia }\end{array}$ & 6.412630 & $\mathrm{H} 0=$ no causality & 0.0113 & rejected & negative \\
\hline $\begin{array}{l}\text { From sum of export and import } \\
\text { shares of ASEAN share with } \\
\text { GCC to sum of intra export and } \\
\text { import shares of GCC }\end{array}$ & 12.13364 & $\mathrm{HO}=$ no causality & 0.0005 & rejected & positive \\
\hline $\begin{array}{l}\text { From sum of export and import } \\
\text { shares of SAARC share with } \\
\text { GCC to sum of intra export and } \\
\text { import shares of GCC }\end{array}$ & 15.11967 & $\mathrm{HO}=$ no causality & 0.0001 & rejected & negative \\
\hline
\end{tabular}

Source: Calculated by author.

In this VECM, there are three roots whose values are one that's why the model is non-stationary. In Table 14 the values of roots are given.

Table 14. The values of Roots

\begin{tabular}{|l|l|}
\hline Root & Modulus \\
\hline 1.000000 & 1.000000 \\
\hline 1.000000 & 1.000000 \\
\hline 1.000000 & 1.000000 \\
\hline-0.858510 & 0.858510 \\
\hline 0.838188 & 0.838188 \\
\hline $0.506261-0.506195 \mathrm{i}$ & 0.715915 \\
\hline $0.506261+0.506195 \mathrm{i}$ & 0.715915 \\
\hline 0.253390 & 0.253390 \\
\hline
\end{tabular}

Source: Calculated by author.

The VECM model is stable because all the roots lie on or inside the unit circle which are shown in the Figure 8.

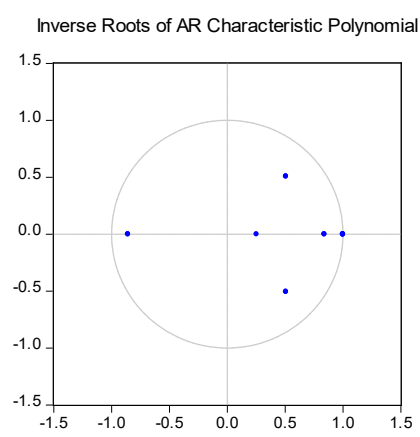

Figure 8. The Unit circle 
The impulse response functions revealed that the response of GDPA to ASEANC trade reached equilibrium in the seven and eight years and then moved divergent and the response of GDPA to SAARCC trade reached equilibrium at first year and 3.8 years and then tended divergent. The response of the sum of the intra export and import shares of GCC reached equilibrium after 5.5 and 6.5 years and then moved away from equilibrium. The other responses did not reach to equilibrium at any time in courses of divergence. These impacts are shown in the Figure 9.

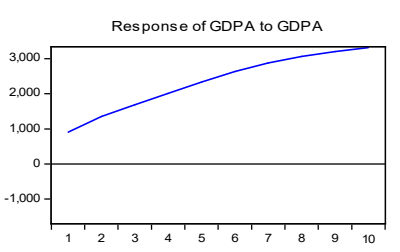

Response of IX+IM to GDPA
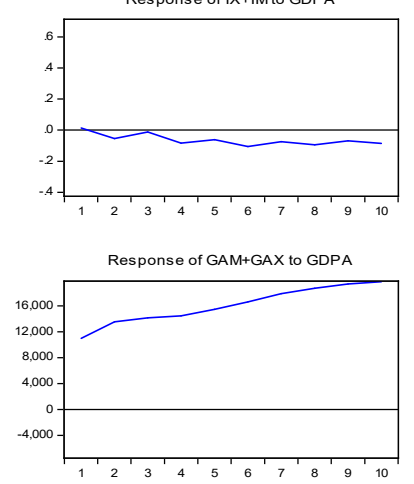

Response of GSM+GSX to GDPA

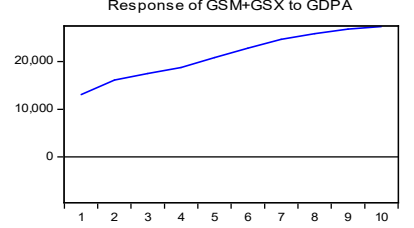

Source: Plotted by author
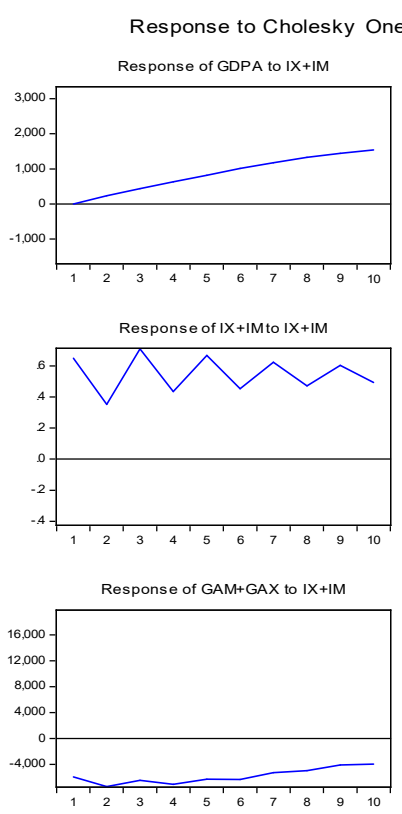

Response of GSM+GSX to IX+IM

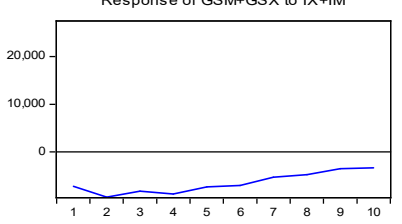

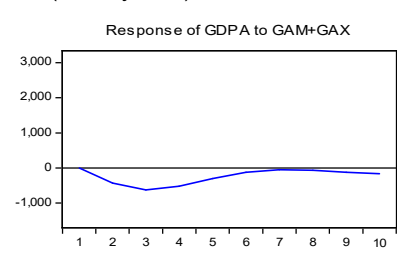

Response of IX+IM to GAM+GAX
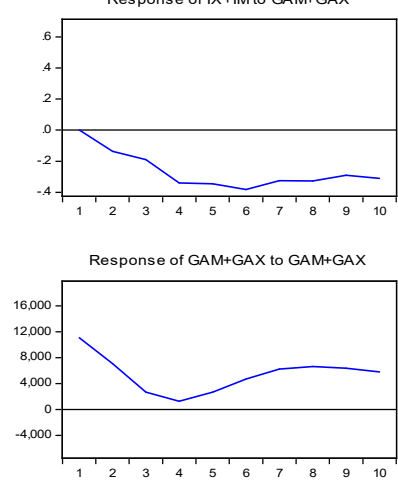

Response of GSM+GSX to GAM+GAX

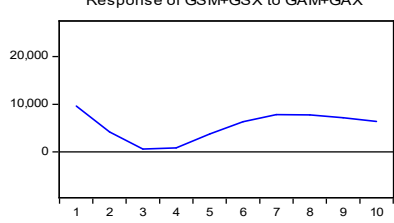

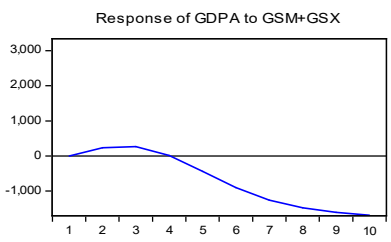

Response of IX+IM to GSM+GSX
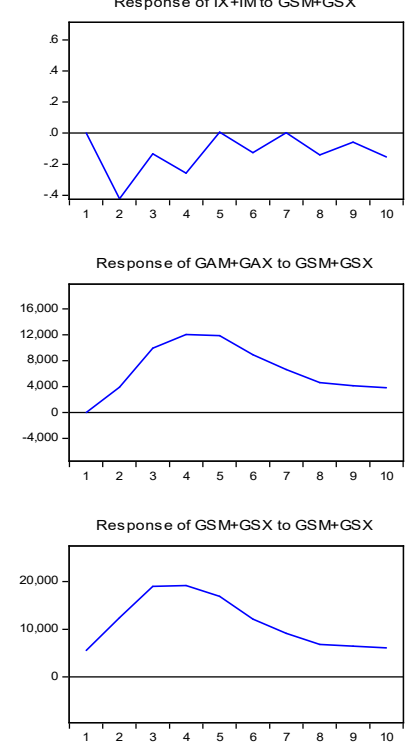

Figure 9. The Impulse Response Functions.

Not but the least, it is noted that the correlation matrix implied that the correlations between GDP of Asia and the sum of the intra export and import shares of GCC, the sum of the export and import shares of ASEAN and SAARC with GCC are found positive that justified that the GCC has great influence on the economic integration process of Asia. With the obvious reasons, the correlation coefficients among sum of intra exports and imports of GCC with the sum of exports and imports of GCC with SAARC and ASEAN were found negative. The correlation matrix is given below.

\section{The Correlation matrix of VECM}

$\begin{array}{lcccc} & \text { GDPA } & \text { IX+IM } & \text { GAM+GAX } & \text { GSM+GSX } \\ \text { GDPA } & 1 & 0.0203 & 0.6583 & 0.7019 \\ \text { IX+IM } & 0.0203 & 1 & -0.3398 & -0.3736 \\ \text { GAM+GAX } & 0.6583 & -0.3398 & 1 & 0.9427 \\ \text { GSM+GSX } & 0.7019 & -0.3736 & 0.9427 & 1\end{array}$

\section{Some limitations and scope of future research}

The paper has some limitations too. The impact of monetary and financial integration of GCC with SAARC and ASEAN in the process of Asian regional integration was excluded in the analysis due to lack of most influential time series financial and monetary indicators. This important area is left for future research which will be a significant extended analysis of the paper. Since, the possible policies that can accelerate the economic integration process of Asian region are debatable and belong to the political dimensions then the paper excludes 
that part. The GCC-East Asia integration is also excluded here due to non-availability of data and low integration status.

\section{Conclusion}

The influence and functions of GCC on the progress of Asian Economic Integration in association with SAARC and ASEAN are to be explored because it can also integrate East, South and West Asia as well. How East Asian monetary integration can be integrated with common currency framework of GCC in course of monetary and financial integration in Asian bloc is a phenomenon of research which can claim novelty. Yet, the paper concludes that the export share of Asia has long run association with intra export share of GCC, export concentration index of GCC, export shares of SAARC and ASEAN with GCC showing three cointegrating equations. The export share of Asia has long run causalities with export shares of SAARC and ASEAN with GCC which is significantly approaching towards equilibrium with speed of adjustment of $42 \%$ and the intra export share of GCC has long run causalities with export shares of SAARC and ASEAN with GCC which is significantly approaching towards equilibrium with the speed of adjustment of $63.7 \%$ per year. The export concentration index has short run causalities with export of ASEAN and SAARC with GCC, the intra export share of GCC and the export share of GCC has short run causality with the export share of ASEAN with GCC. The import share of Asia showed three cointegrating equations where import concentration index and the intra import share of GCC have significant long run causalities from import shares of SAARC and ASEAN with GCC which are approaching towards equilibrium significantly but the import share of Asia has insignificant long run causalities with them. The intra import share of GCC has short run causalities with the Import share of Asia, Import concentration index of GCC and the import share of ASEAN with GCC respectively. The import concentration index has short run causality with the import share of Asia. The import share of SAARC with GCC has short run causality with the import share of ASEAN with GCC. All of these findings revealed that the Gulf Cooperation Council affected the process of economic integration of Asia. The GDP of Asia has long run causalities with the sum of the intra export and import shares of GCC, the sum of the export and import shares of ASEAN with GCC and the sum of the export and import shares of SAARC with GCC where causal relations are significant. There is a short run causality from sum of the export and import shares of ASEAN shares with GCC to the GDP of Asia and there are short run causalities from the sum of the export and import shares of ASEAN and SAARC shares with GCC to the sum of the intra export and import shares of GCC respectively during 1995-2019. These observations imply that economic integration of GCC has quite influence on the development process of Asia.

\section{References}

1. Asian Development Bank. (2021, February). Asian Economic Integration Report 2021. http://dx.doi.org/10.22617/TCS210048-2

2. Adhikari, Santosh., Gale, Fred., \& Vince, Joanna. (2019). Labour Migration Management in South Asia Region. Fourth International Conference on Public Policy (ICPP4). Concordia University. Retrieved from: https://www.ippapublicpolicy.org/file/paper/5cfd028c99031.pdf

3. Al-Tamimi, Naser. (2013). Asia GCC Relations Growing Interdependence. (Institute for International Policy Studies. No-179). Retrieved from: https://www.ispionline.it/sites/default/files/pubblica zioni/analysis 179 2013.pdf

4. Bhowmik, Debesh. (2014). Asian Economic Integration: Feasibility of an India-led Economic Bloc. New Delhi: Regal Publication. Retrieved from: https://library.oapen.org/bitstream/id/bdae098c-2d8c-4e53a5bd-5dadef15f713/643793.pdf

5. Burton, Guy. (2020, February). Connectivity Between the Gulf Cooperation Council and Asia. (Research Paper-5), Bussola Institute. Retrieved from: https://www.bussolainstitute.org/wp-content/uploads/2020/ 02/GCC-and-Asian-Connectivity_Paper-V3.pdf

6. Calder, Kent, E. (2015, August). The United States, Japan and The Gulf Region. The Sasakawa Peace Foundation. Retrieved from https://www.spf.org/global-data/SPF 20170810 01.pdf

7. Chen, Mo. (2011). Exploring Economic Relations between China and the GCC States. Journal of Middle Eastern and Islamic Studies (in Asia), 5(4), 88-105. https://doi.org/10.1080/19370679.2011.12023192

8. Cinar, E.M., Johnson, J., \& Geusz, K. (2016). Estimating Chinese relationship with the Silk Road countries. China \& World Economy,24(1), 85-103. https://doi.org/10.1111/cwe.12145 
9. Janardhan, N. (2014, October). GCC-Asia Ties and Collective Security. (Gulf Research Center Gulf Papers). Retrieved from: https://www.files.ethz.ch/isn/185692/Unity_10_Janarthan_new_8687.pdf

10. Johansen, S. (1988). Statistical Analysis of Cointegrating Vectors. Journal of Economic Dynamics and Control, 12, 231-254. Retrieved from: https://econpapers.repec.org/RePEc:eee:dyncon:v:12:y:1988:i:23:p:231-254

11. Johansen, S. (1991). Estimation and Hypothesis Testing of Cointegration Vectors in Gaussian Vector Autoregressive Models. Econometrica, 59(6), 1551-60. Retrieved from: https://EconPapers.repec.org/ RePEc:ecm:emetrp:v:59:y:1991:i:6:p:1551-80

12. Kodithuwakku, Sarath., Weerahewa, Jeevika., \& Boughaumi, Houcina. (2016, December). Food and Agricultural Trade in GCC: An opportunity for South Asia? Review of Middle East Economics and Finance, 12(3). https://doi.org/10.1515/rmeef-2016-0010

13. Koerner, Kevin. (2014, February). The GCC going East: Economic ties with developing Asia on the rise. Deutsche Bank Research, Germany Monitor. Retrieved from: https://docplayer.net/16945288-Gcc-intimes-of-cheap-oil-an-opportunity-for-economic-reform-and-diversification.html

14. MacKinnon, J., Haug, A., \& Michelis, L. (1999). Numerical Distribution Functions of Likelihood Ratio Test for Cointegration. Journal of Applied Econometrics, 14(5),563-577. http://qed.econ.queensu.ca:80/ jae/1999-v14.5/

15. Nayyar, Dhiraj. (2018). India's Asian trade strategy. In Shiro, Armstrong \& Tom, Westland (Eds.), Asian Integration in an era of Global Integrity. Australia: ANU Press. (Chapter-8). Retrieved from:www.pressfiles.anu.edu.au

16. Pangestu, Mari., \& Armstrong, Shiro. (2018). Asian Economic Integration in an Era of Global Uncertainty. In Shiro, Armstrong \& Tom, Westland (Ed.), Asian Integration in an era of Global Integrity. Australia: ANU Press. (Chapter-2)._Retrieved from:_www.press-files.anu.edu.au anu.edu.au

17. Pradhan, Samir Ranjan. (2010). Gulf-South Asia Economics Relations; Realities and Prospects. Centre for Economic Policy Research. Retrieved from: http://www.globaltradealert.org/sites/default/files/GTA4.pdf

18. UKEssays. (2018, November). Free Trade Agreement Between GCC and ASEAN. Retrieved from: https://www.ukessays.com/essays/economics/free-trade-agreement-between-the-gcc-and-asean-economi cs-essay.php

19. UNESCAP. (2017). Unlocking the potential of regional economic cooperation and integration in South Asia: Potential, challenges and the way forward. Bangkok: Retrieved from: https://www.unescap.org/publications/unlocking-potential-regional-economic-cooperation-and-integrati on-south-asia-potential

20. Song, NIU. (2010). The Economic and Trade Cooperation between ASEAN and the Gulf Cooperation Council, Journal of Middle Eastern and Islamic Studies (in Asia), 4(4), 82-101, https://doi.org/10.1080/19370679.2010.12023169

21. Wald, Abraham. (1943). Test of Statistical Hypothesis concerning several parameters when the number of observations is large. Transactions of American Mathematical Society,54,426-82. Retrieved from http://www.jstor.org/stable/1990256

22. Wilson, R. (2004). Economic Relation Between GCC and South and South East Asia. In H. Carter, Anoushiravan Ehteshmi (Eds.), The Middle East Relation with Asia and Russia. Routledge Curzon. Retrieved from https://www.routledge.com/The-Middle-Easts-Relations-with-Asia-and-Russia/CarterEhteshami/p/book/9780415650137

23. Zhen, Y.U., \& Xinyi, BAI. (2017). From South East Asia to the Gulf: Analysis of the Prospect of Indian Ocean Integration. Asian Journal of Middle Eastern and Islamic Studies, 11(3),90-106, https://doi.org/10.1080/25765949.2017.12023312

\section{Acknowledgement}

The author declares that no funds from any source and no technological and other helps from any authority have been taken in preparing this paper. There is no conflict of interest in preparation of this paper. The author is responsible for all the errors and omissions. 


\section{Appendix}

\section{Data used in this paper}

IX=Intra export share of GCC ( $\%$ of bloc), IM=Intra import share of GCC ( $\%$ of bloc), XCI=export concentration index of GCC, ICI=Import concentration index of GCC, GAM=Import of GCC from ASEAN (in million US\$), GAX=export of GCC from ASEAN (in million US\$), GSM=import of GCC from SAARC (in million US\$), GSX=export of GCC from SAARC (in million US\$), GDPA=GDP of Asia in billion US\$., $\mathrm{XA}=$ export share of Asia (\% of world), IA=Import share of Asia (\% of the world).

\begin{tabular}{|c|c|c|c|c|c|c|c|c|c|c|c|}
\hline & GAM & GAX & GDPA & GSM & GSX & IA & $\mathrm{ICl}$ & IM & IX & XA & $\mathrm{XCl}$ \\
\hline 1995 & 4614 & 11648 & 9213 & 3004 & 7910 & 28.72 & 0.054 & 8.91 & 6.22 & 30.156 & 0.614 \\
\hline 1996 & 5102 & 15581 & 8987 & 3832 & 9978 & 29.049 & 0.053 & 9.31 & 6.67 & 29.678 & 0.622 \\
\hline 1997 & 4911 & 15034 & 8697 & 4366 & 10405 & 28.55 & 0.066 & 9.04 & 6.43 & 30.236 & 0.584 \\
\hline 1998 & 4782 & 9731 & 7895 & 4371 & 7746 & 24.44 & 0.066 & 8.78 & 7.96 & 28.347 & 0.555 \\
\hline 1999 & 4648 & 13927 & 8772 & 4353 & 11322 & 25.31 & 0.062 & 9.23 & 7.16 & 29.762 & 0.57 \\
\hline 2000 & 4854 & 19535 & 9480 & 4676 & 12287 & 27.41 & 0.068 & 12.26 & 6.22 & 32.038 & 0.579 \\
\hline 2001 & 5021 & 17874 & 8883 & 4735 & 10079 & 26.66 & 0.075 & 10.95 & 6.67 & 30.378 & 0.531 \\
\hline 2002 & 5266 & 18249 & 9101 & 5518 & 11219 & 27.29 & 0.075 & 10.98 & 7.39 & 31.252 & 0.517 \\
\hline 2003 & 5977 & 21496 & 10046 & 7641 & 14121 & 27.86 & 0.074 & 10.85 & 6.79 & 31.895 & 0.506 \\
\hline 2004 & 7906 & 29892 & 11333 & 11060 & 21056 & 29.07 & 0.075 & 11.64 & 6.92 & 32.995 & 0.52 \\
\hline 2005 & 10347 & 43847 & 12371 & 12959 & 29107 & 29.86 & 0.076 & 11.57 & 6.17 & 34.184 & 0.551 \\
\hline 2006 & 12499 & 51988 & 13409 & 16071 & 45586 & 30.116 & 0.075 & 11.98 & 6.03 & 34.931 & 0.559 \\
\hline 2007 & 16691 & 59408 & 15297 & 21966 & 61060 & 30.33 & 0.073 & 10.68 & 6.47 & 35.158 & 0.576 \\
\hline 2008 & 22164 & 81688 & 17653 & 33914 & 90699 & 31.799 & 0.075 & 10.77 & 6.38 & 35.881 & 0.598 \\
\hline 2009 & 19563 & 50983 & 17924 & 34507 & 65419 & 33.067 & 0.068 & 9.91 & 7.61 & 36.749 & 0.513 \\
\hline 2010 & 20435 & 64409 & 20931 & 38231 & 90217 & 35.367 & 0.074 & 10.64 & 6.74 & 38.917 & 0.506 \\
\hline 2011 & 24304 & 99141 & 24258 & 49116 & 132309 & 36.342 & 0.073 & 11.8 & 6.49 & 39.316 & 0.529 \\
\hline 2012 & 30948 & 109436 & 25713 & 48647 & 144962 & 37.589 & 0.085 & 10.77 & 6.23 & 40.422 & 0.502 \\
\hline 2013 & 35836 & 117313 & 26150 & 50890 & 148915 & 37.966 & 0.091 & 12.19 & 7.93 & 40.327 & 0.5 \\
\hline 2014 & 38389 & 106456 & 26977 & 48601 & 132833 & 37.76 & 0.081 & 11.66 & 8.06 & 40.651 & 0.481 \\
\hline 2015 & 38526 & 68771 & 26639 & 47680 & 89950 & 37.37 & 0.087 & 9.89 & 11.24 & 41.473 & 0.358 \\
\hline 2016 & 31496 & 59029 & 27618 & 45840 & 82030 & 36.73 & 0.087 & 9.83 & 10.91 & 40.913 & 0.347 \\
\hline 2017 & 31895 & 72922 & 29559 & 41902 & 96952 & 37.659 & 0.087 & 11.11 & 10.52 & 41.111 & 0.354 \\
\hline 2018 & 30376 & 91150 & 31814 & 42793 & 111425 & 37.97 & 0.083 & 12.45 & 9.8 & 41.019 & 0.4 \\
\hline 2019 & 31045 & 79003 & 35145 & 42965 & 108887 & 37.747 & 0.086 & 12.01 & 10.66 & 40.875 & 0.393 \\
\hline
\end{tabular}

Source: UNCTAD (www.unctad.org). 